\title{
Idaho National Laboratory Cultural Resource Management Annual Report FY 2006
}

Julie B. Braun

Hollie K. Gilbert

Dino L. Lowrey

Clayton F. Marler

Brenda R. Pace

April 2007

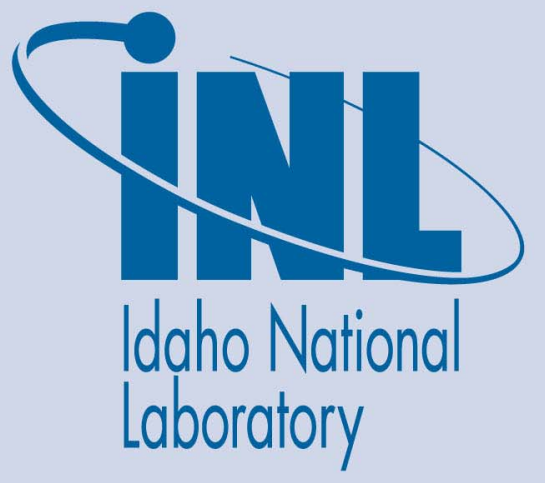

The INL is a U.S. Department of Energy National Laboratory operated by Battelle Energy Alliance 


\section{Idaho National Laboratory Cultural Resource Management Annual Report FY 2006}

Julie B. Braun

Hollie K. Gilbert

Dino L. Lowrey

Clayton F. Marler

Brenda R. Pace

April 2007

Idaho National Laboratory
Idaho Falls, Idaho 83415

Prepared for the

U.S. Department of Energy

Office of Nuclear Energy

Under DOE Idaho Operations Office

Contract DE-AC07-05ID14517 


\section{ABSTRACT}

The Idaho National Laboratory Site is home to vast numbers and a wide variety of important cultural resources representing at least a 13,500-year span of human occupation in the region. As a federal agency, the Department of Energy Idaho Operations Office has legal responsibility for the management and protection of those resources and has delegated these responsibilities to its primary contractor, Battelle Energy Alliance (BEA). The INL Cultural Resource Management Office, staffed by BEA professionals, is committed to maintaining a cultural resource management program that accepts these challenges in a manner reflecting the resources' importance in local, regional, and national history.

This annual report summarizes activities performed by the INL Cultural Resource Management Office staff during Fiscal Year 2006. This work is diverse, far-reaching and though generally confined to INL cultural resource compliance, also includes a myriad of professional and voluntary community activities. This document is intended to be both informative to internal and external stakeholders, and to serve as a planning tool for future cultural resource management work to be conducted on the INL. 


\section{CONTENTS}

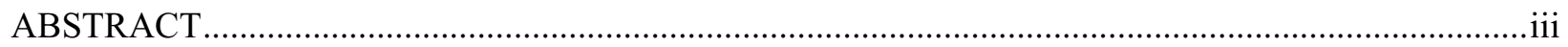

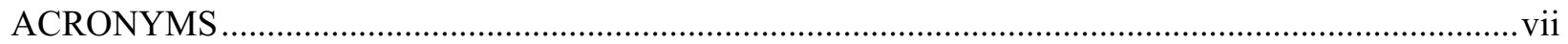

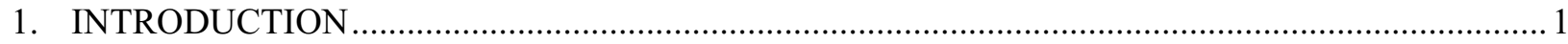

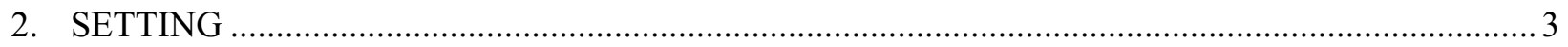

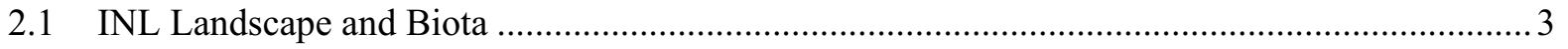

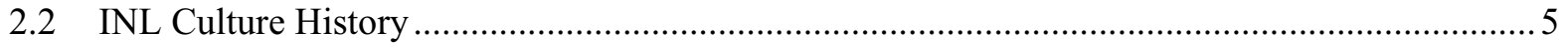

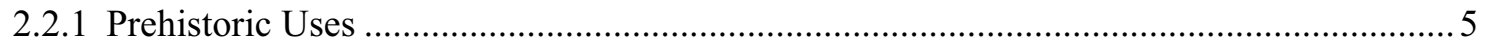

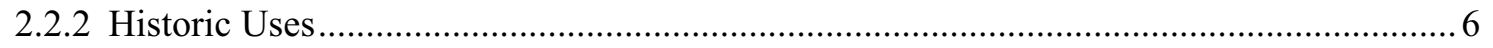

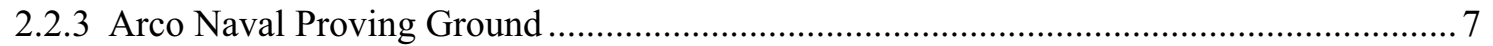

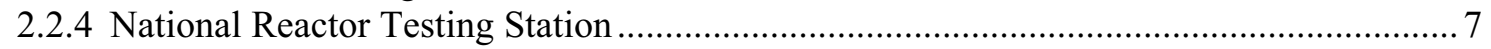

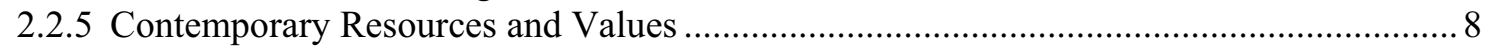

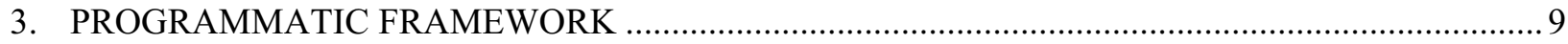

4. INL CULTURAL RESOURCE PROGRAM PERSONNEL …....................................................... 10

5. CULTURAL RESOURCE MANAGEMENT OFFICE ACTIVITIES ..........................................11

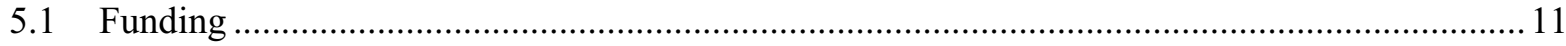

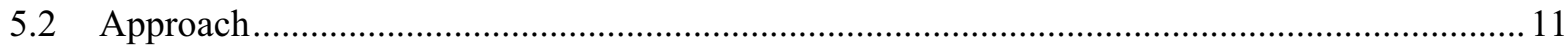

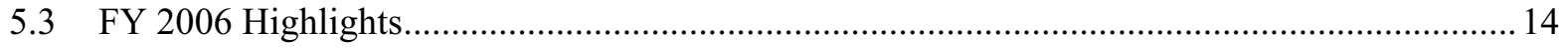

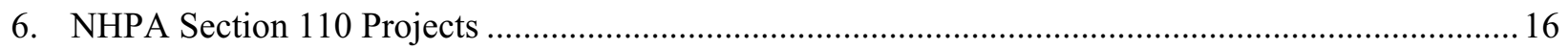

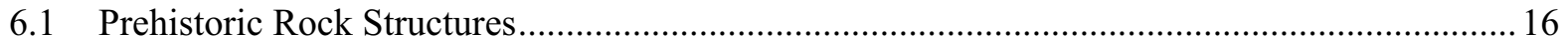

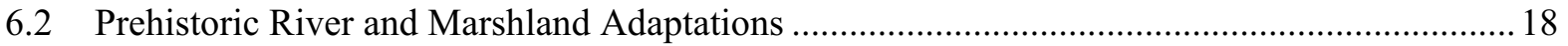

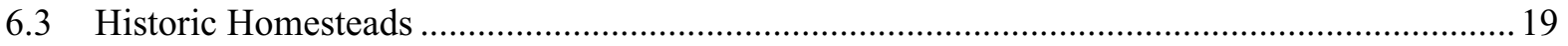

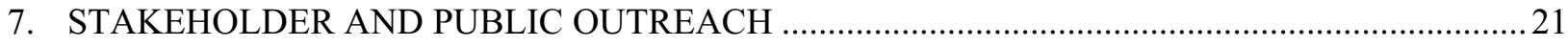

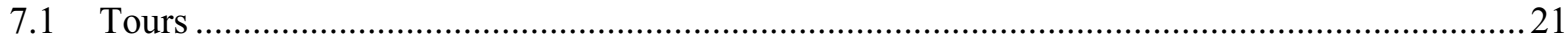

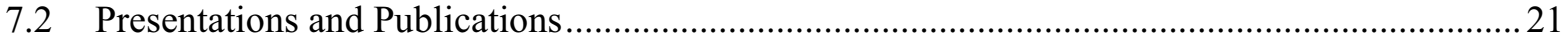

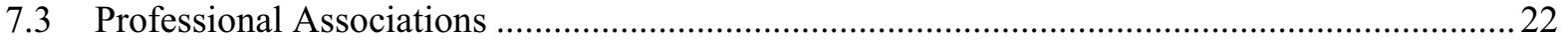

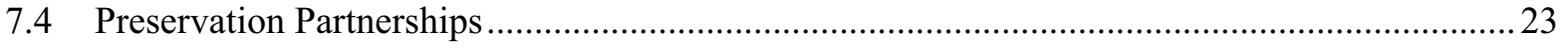

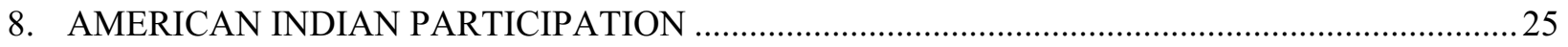

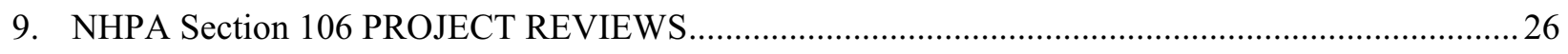

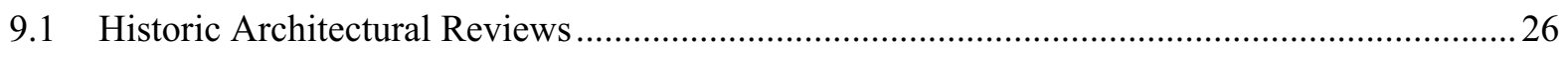

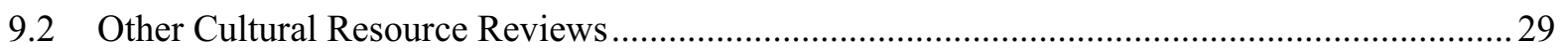


10. SITE AND PROJECT MONITORING

11. FISCAL YEAR 2007 ACTIVITIES

12. REFERENCES

\section{TABLES}

Table 1: Historic architectural project reviews completed in FY 2006...........................27

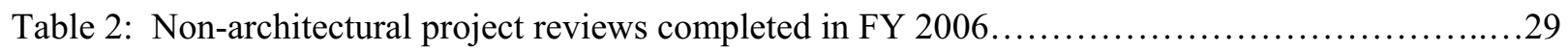

Cover photograph is of a summer 2006 Science Camp participant showing off an artifact she discovered at an INL homestead. This and all other photographs in the document were taken by INL CRMO staff. 


\section{ACRONYMS}

ACHP Advisory Council on Historic Preservation

AEC U.S. Atomic Energy Commission

AIP Agreement In Principle

AIRFA American Indian Religious Freedom Act

ANPG Arco Naval Proving Ground

ARPA Archaeological Resource Protection Act

BBWI Bechtel Babcock \& Wilcox Idaho

BEA Battelle Energy Alliance

CFA Central Facilities Area

CDRL Contract Data Requirements List

CITRC Critical Infrastructure Test Range Complex

CRM Cultural Resource Management

CRMP Cultural Resource Management Plan

CRMO Cultural Resource Management Office

CRWG Cultural Resources Working Group

CWI CH2M Hill/Washington Group International

DD\&D decontamination, deactivation, and demolition

DOE-ID U.S. Department of Energy - Idaho Operations Office

DOI Department of Interior

EBR I Experimental Breeder Reactor I

$\mathrm{ft} \quad$ foot

FTE full-time equivalent

FY fiscal year

HAER Historic American Engineering Record

HeTO Heritage Tribal Office (Shoshone-Bannock)

ICP Idaho Completion Project

in inch 


\begin{tabular}{|c|c|}
\hline INEL & Idaho National Engineering Laboratory \\
\hline INEEL & Idaho National Engineering and Environmental Laboratory \\
\hline INL & Idaho National Laboratory \\
\hline INTEC & Idaho Nuclear Technology and Engineering Center \\
\hline ISMS & Integrated Safety Management System \\
\hline ITD & Idaho Transportation Department \\
\hline LMT & Leadership Management Team \\
\hline MOA & memorandum of agreement \\
\hline MFC & Materials and Fuels Complex \\
\hline NEPA & National Environmental Policy Act \\
\hline NHPA & National Historic Preservation Act \\
\hline NPS & National Park Service \\
\hline NRF & Naval Reactors Facility \\
\hline NRHP & National Register of Historic Places \\
\hline NRTS & National Reactor Testing Station \\
\hline OCTA & Oregon and California Trails Association \\
\hline PA & Programmatic Agreement \\
\hline PBF & Power Burst Facility \\
\hline PL & Public Law \\
\hline RTC & Reactor Technology Complex \\
\hline RWMC & Radioactive Waste Management Complex \\
\hline SHPO & State Historic Preservation Office \\
\hline TAN & Test Area North \\
\hline TRA & Test Reactor Area \\
\hline USC & United States Code \\
\hline USGS & U.S. Geological Survey \\
\hline WWII & World War II \\
\hline
\end{tabular}




\section{INL CULTURAL RESOURCE MANAGEMENT OFFICE ANNUAL REPORT FY 2006}

\section{INTRODUCTION}

The Idaho National Laboratory (INL) is a multi-program laboratory located in southeast Idaho under the jurisdiction of the Department of Energy Idaho Operations Office (DOE-ID). The INL consists of an 890 square mile reserve located approximately 30 miles west of Idaho Falls Idaho, along with a number of administrative buildings and laboratories located in Idaho Falls. Management and operations at the INL Site are under the direction of the Battelle Energy Alliance (BEA), while other contractors and subcontractors such as $\mathrm{CH} 2 \mathrm{M}$ Hill/Washington Group International (CWI) and Bechtel BWXT Idaho (BBWI) implement specific work scopes. DOE-ID and its contractors occupy eight main facilities at the INL Site along with the facilities in Idaho Falls, Idaho. Bechtel Bettis operate a ninth INL facility, the Naval Reactors Facility (NRF), under the supervision of the DOE Office of Naval Reactors.

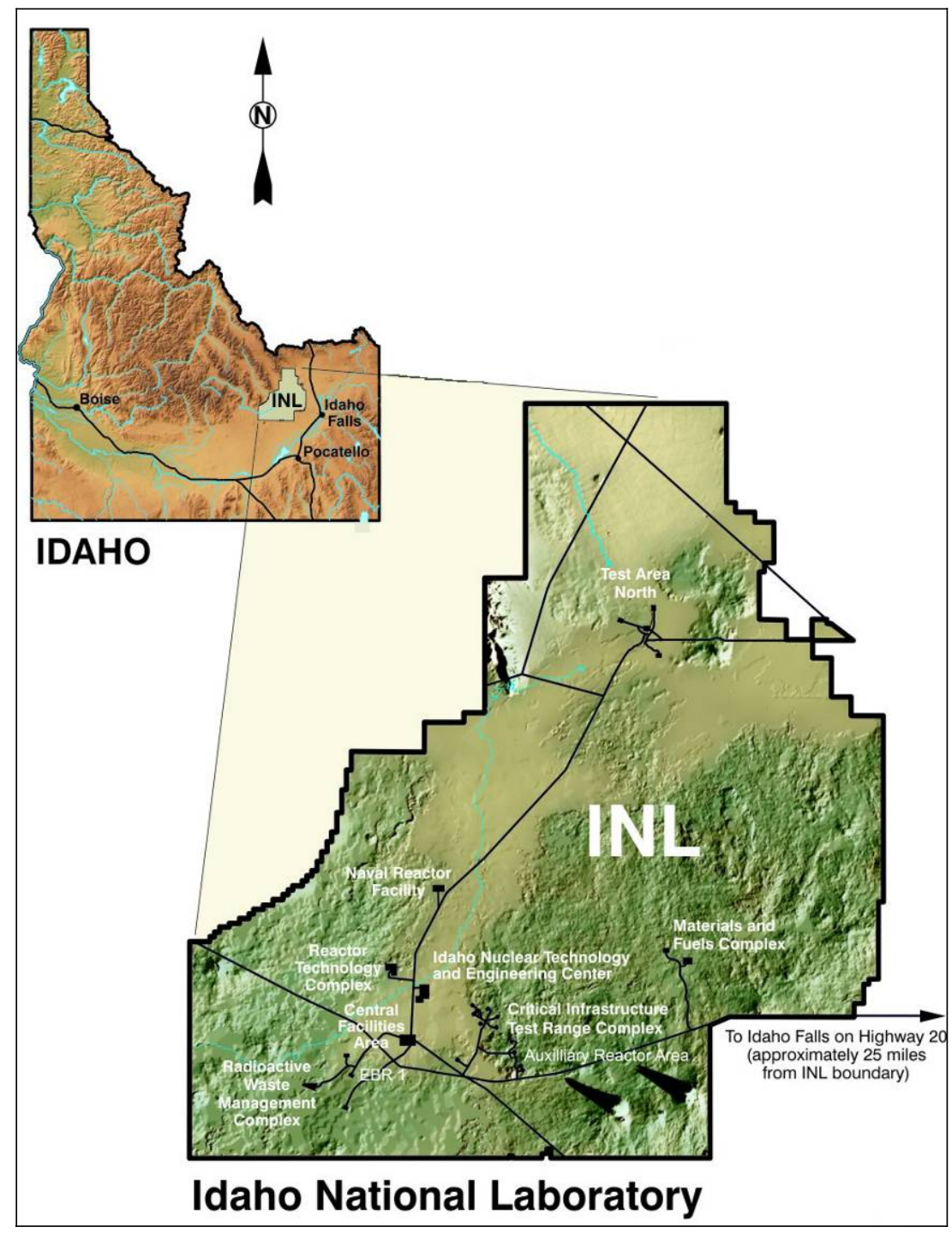

Shaded relief map depicting Idaho National Laboratory location within the State of Idaho 
Cultural resource management (CRM) at the INL is conducted and coordinated by BEA's professional staff with general oversight provided by DOE-ID. As the centralized repository for both cultural resource archives and expertise, the INL Cultural Resource Management Office (CRMO) also assists other Site contractors with project reviews and regulatory compliance.

This summary of activities is an annual effort by the INL CRMO that satisfies a major requirement of the INL Cultural Resource Management Plan (CRMP) (DOE-ID 2007) and associated programmatic agreement between the DOE-ID, Idaho State Historic Preservation Office (SHPO), and Advisory Council on Historic Preservation (ACHP). It is intended for a diverse audience and to encourage awareness of and appreciation for, INL cultural resources. Photographs taken by INL CRMO staff. provide a visual context for many of the interesting activities discussed in the text. Ultimately, the document is intended to stimulate discussion resulting in enhanced relevance and effectiveness for the INL CRM program. Its completion in conjunction with an annual public tour of INL cultural resources and meeting with the SHPO is intended to encourage this active feedback. 


\section{SETTING}

\subsection{INL Landscape and Biota}

The INL is an 890 square mile reserve located on the northern margins of the Eastern Snake River Plain (Nace et al. 1972), tucked against the foothills of the Beaverhead, Lemhi, and Lost River Ranges. Locally prominent landmarks such as Big Southern, Middle, East, Antelope, and Circular Buttes are volcanic in origin and tend to dominate a landscape that appears deceptively flat. In reality, the lava terrain features ridges and swales, playas, craters, buttes, and caves. The Big Lost River has created a broad and relatively flat floodplain that is bordered by the undulating basaltic terrain. Extensive gravel deposits and a multitude of channels characterize the floodplain and reflect a more active period in the River's history.

The broad trough of the Big Lost River is also known as the Pioneer Basin (Butler 1968). It is a closed topographic depression, fed by drainage systems that extend between Big Southern, Middle, and East Buttes to the south, and Mud Lake, the Big and Little Lost Rivers, and Birch Creek to the north. The central feature of the Basin is the Big Lost River itself, which enters the Site from the west, flowing southeasterly for about six miles before abruptly turning to the northeast and finally to the north. Along the way it winds through a broad alluvial plain interspersed with basalt outcrops and cut by numerous channels for some 25 miles before a combination of stream flow rates, gradient, and soil porosity cause the River to disappear or "sink" into the Snake River Plain Aquifer in a low area at the base of the Lemhi Mountains. The Little Lost River and Birch Creek also terminate in natural "sink" areas at the northeastern end of the Pioneer Basin.

The Big Lost River has endured significant natural and artificial modifications during its long

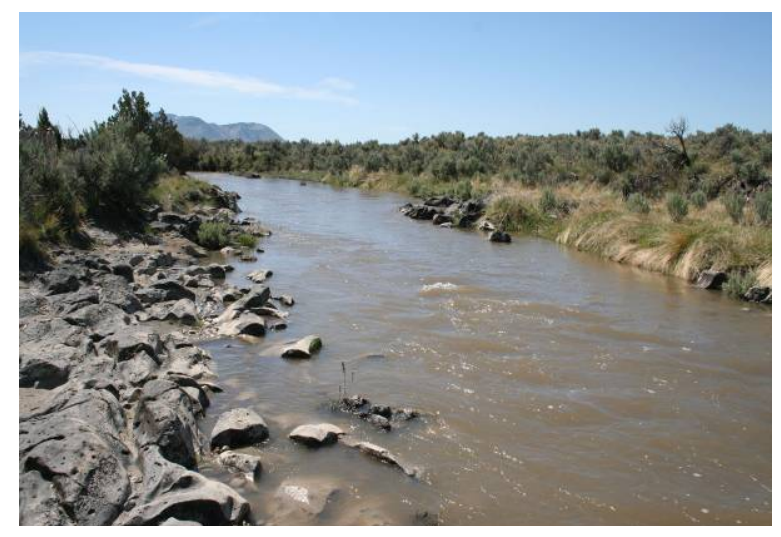

Big Lost River 2006 early spring runoff history and natural channels that may have held water during times of greater effective moisture remain dry today due to cyclic drought combined with large-scale irrigation projects initiated in the early $20^{\text {th }}$ century. The "sinks" have also been affected by climate change and historic irrigation practices. Today they are seasonal wetlands that remain dry most years, but in the past during cooler and wetter conditions, they were part of a major inland lake known as Lake Terreton.

Lake Terreton was a shallow freshwater lake that dominated the northern reaches of the Pioneer Basin spreading over hundreds of square kilometers (Butler 1970, Gianniny et al. 2002, Ostenaa 1999) at the end of the Pleistocene, about 13,000 years ago. On lands now within the boundaries of INL, greater effective moisture and reliable flows from Birch Creek and the Big and Little Lost Rivers fed a western sub-basin of the Lake approximately 90 square miles in extent. Farther to the east, Camas and Beaver Creeks sustained an eastern sub-basin known today as Mud Lake, located roughly 20 miles east of the INL. During the Pleistocene the desert was wetter and cooler and as might be expected, the local rivers, Lake Terreton, and the numerous smaller playas that dot the landscape significantly influenced plant communities. Warming and drying trends since the end of the Pleistocene and into modern times have resulted in changes in the relative percentages of each plant species but virtually all species that existed then still exist today (Davis and Bright 1983). 
Throughout INL history, water has been central in human land-use choices. Surface features like the streams, rivers, and large seasonal wetlands created at the "sinks" have attracted animals and human hunter-gatherers, farmers, and ranchers with the lure of moisture in the cold desert environment. During cooler and moister climatic intervals from $22,000-11,000$ years ago and possibly as recently as 720 years ago, INL CRMO research suggests that hunter-gatherers were drawn to the resources offered by Lake Terreton. As conditions have dried in historic times, water has become more scarce, reducing Lake

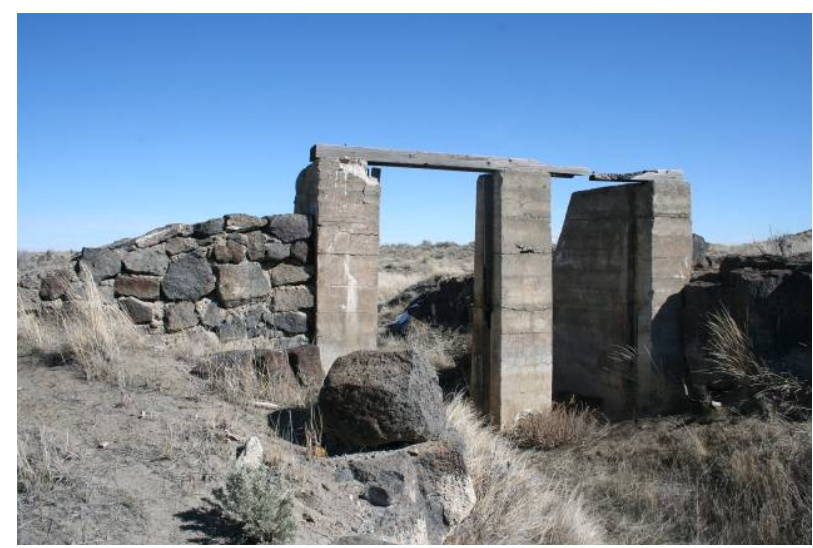

ca. 1910 concrete diversion on the

Big Lost River
Terreton to a semi-seasonal marsh and largely restricting overland flow to the main channels of the rivers. Diversions of many kinds, including simple modifications to ancient channels as well as carefully engineered canals and hand-dug ditches, were created all over the INL desert during historic times to deliver the precious water to hopeful settlers on homestead claims systematically established throughout the Pioneer Basin from the late 1800 s through approximately 1925 . Later, surface water became increasingly scarce and recurrent cycles of drought strongly affected these local settlements leading to abandonment. INL CRMO research is filling in many of the details of the lives of these pioneers, and the inevitable cycles of boom and bust linked intimately to water. In

modern times, the extensive aquifer fed by these surface features has become accessible through enhanced technology and new needs based in scientific endeavor.

Modern biotic communities on the INL are similar to those found in other cool desert environments within the Great Basin. Plant species vary according to altitude from shad scale steppe to sagebrush and grass dominated communities to environments dominated by juniper at higher altitudes along the slopes of the larger buttes and the mountain foothills. Various native grasses, low shrubs, and cacti are present in virtually all plant communities (Anderson et al 1996). In addition to environmental changes, human activity, most notably within historic times, has affected INL vegetation. Agricultural attempts have left visible field scars and have introduced non-

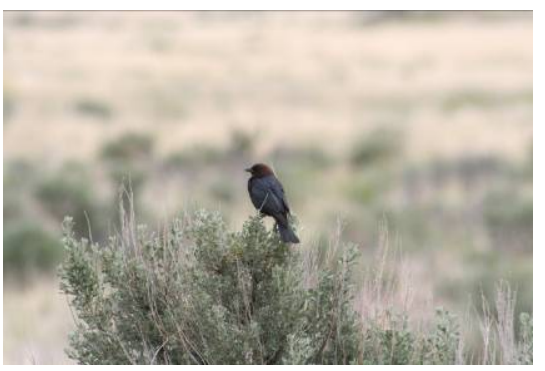

Brown-headed Cowbird native crop species. Range fires and roads have destroyed native vegetation and provided pathways for

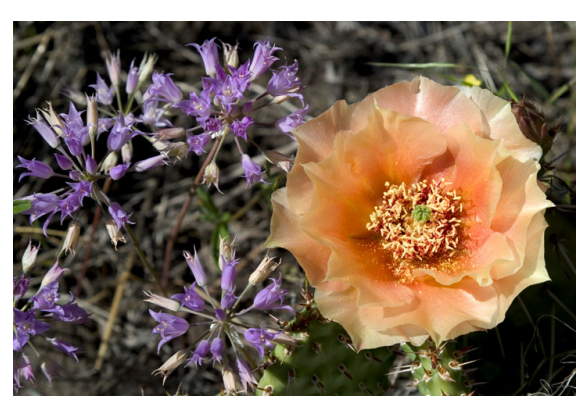

invasive species such as cheat grass. Riparian plant communities including willow and large cottonwood trees, that existed until relatively recent times have generally not survived modern cycles of drought and upstream water diversion.

Toward the end of the Pleistocene a number of large faunal species such as mammoth and camel became extinct and during more recent times, species such as bison have also disappeared from the Snake River Plain. Modern INL faunal communities consist of terrestrial vertebrate species such as pronghorn, deer, Wild onion and prickly pear cactus in bloom

elk, coyote, badger and fox, along with numerous small mammals such as rabbits, mice, voles and ground squirrels. Reptilian species include a number of lizard species, the most abundant of which is the sagebrush lizard. Four species of snake are known to inhabit the area as well. These include the gopher 
snake, the western garter snake, the desert striped whip snake, and western rattlesnake (Sehman and Linder 1976). Avian species are largely migratory, although sage grouse reside in the area year-round. During wet years, the "sink" areas provide a temporary haven for many species of migratory waterfowl. Birds of prey, including owls, hawks, eagles, and falcons (Craig and Trost 1976) also occupy the INL area on a seasonal basis.

\subsection{INL Culture History}

The Pioneer Basin and surrounding lava uplands are a stage on which at least 13,500 years of human history has transpired in an intimate relationship with the natural environment. Throughout this lengthy span, human populations have employed different technologies to live in and productively use the cold desert environment. A variety of hunting implements and plant processing tools characterize a lengthy period of seasonal aboriginal hunting and gathering and initial European exploration. Roads and trails were established next and with the arrival of the railroad, they ushered in a period of more focused settlement and landscape changes to support an agrarian lifestyle. Water has always been a limiting factor in permanent settlement of the region, and gross overestimates of abundance combined with regular cycles of drought condemned most of these nineteenth and early twentieth century attempts at settlement to failure. In modern times, the basic transportation infrastructure established by hopeful farmers and irrigation developers and discovery of a vast source of underground water have enabled the U.S. government to establish one-of-a kind facilities at what is now known as the INL. Initially, these activities were devoted to wartime (World War II) efforts and later the lands became host to groundbreaking scientific research.

\subsubsection{Prehistoric Uses}

The relationship between aboriginal hunting and gathering populations and the INL landscape has the deepest roots of all human endeavors in the INL region, enduring for more than 13,000 years without fundamental change. Tangible evidence of this long term land use is ubiquitous, though not randomly distributed on the landscape. The subtleties expressed in the archaeological record are reflective of slight changes through time in the types of resources utilized and the manner in which they were taken. At the end of the last Ice Age, or the Pleistocene, for example, settlement and subsistence appear to have been strongly tied to rivers and marshes, including the marshy edges of Lake Terreton (see Section 6). Water continued to play an important role in settlement and subsistence choices later during the dryer conditions of the Holocene and during a wetter interval when Lake Terreton may have partially filled (Bright and Davis 1982, Mark and Thackray 2002), high vantage points appear to have been intentionally utilized, perhaps because of the commanding view that they provided (see Section 6).

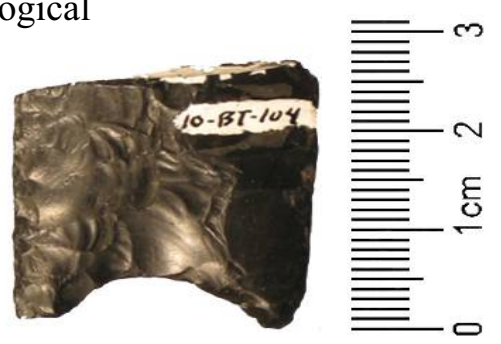

ca. 13,500 year-old Clovis point base found on the INL

Throughout the lengthy period of prehistoric use, the overall lifeway of hunting and gathering appears to have remained consistent as reflected by artifact assemblages recorded at more than 2,250 archaeological sites found during cultural resource inventories. To date, approximately $9 \%$ of the Site has been surveyed for archaeological resources. Predictive models developed to facilitate long-term project planning and ongoing protection of this fragile legacy have provided estimates of as many as 75,000 additional prehistoric archaeological locations that could exist within the INL Site boundaries (Ringe 1995, Plager et al. 2004). 


\subsubsection{Historic Uses}

Since the early 1800s, Euro-American presence has been felt on what is now the INL Site. Initially, land-use was light and transient, perhaps much like that of the early American Indian occupants. Like those earlier people, the first Euro-American occupants were intent on resource extraction. However, unlike the earlier inhabitants, whose focus was on food to sustain life, some were intent on trapping beaver and other animals for monetary purposes. In 1852, Goodale's Cutoff was established as a northern extension of the Oregon Trail; an alternate route to reach the rich resources of the Oregon Territory. Still, this was transient activity, and the human imprint on the landscape remained modest.

Between 1860 and 1880, Goodale's Cutoff came to be used to trail cattle and eventually sheep, from western ranges in Oregon, Washington, and Idaho to eastern markets. During this same time period the mining industry in the mountains of Central Idaho boomed and a number of wagon and stage roads between growing towns and cities along the Snake River and the mining camps of the interior were established. Many of these roads,

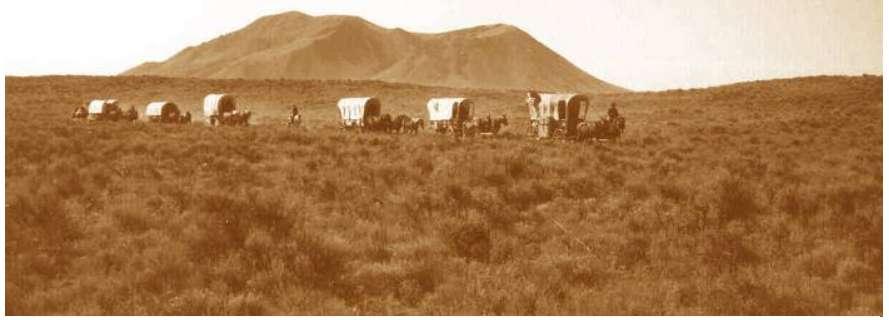
including a portion of Goodale's Cutoff, crossed the Site and, in fact, several are still in use today. By the early 1880 s, a number of ranching operations were underway at the north end of the INL near Howe and around the Big and Little Lost Rivers and the Birch Creek Sinks. Cattle were routinely herded across the Site from these areas to summer range near

1993 Goodale's Cutoff crossing re-enactment on the INL with Big Southern Butte in the background Big Southern Butte (DOE-ID 2007; Gerard 1982).

While Euro-American settlement began near the INL Site in the early 1800s, it wasn't until passage of the Carey Land Act in 1894, and particularly the Desert Reclamation Act in 1902, that homesteading efforts on the arid Site began in earnest. Most of these homesteads were located along the Big Lost River and in the Mud Lake region. Between 1905 and 1920 a number of water-control projects including the Mackay Dam and numerous irrigation canal systems were established on the Big Lost River and in the Mud Lake area. The town of Powell was established adjacent to the Oregon Shortline railroad and the Big Lost River near what is now the Radioactive Waste Management Complex (RWMC) in the southwest corner of the INL and a second townsite, known as McCullum, was planned some distance to the north. An extensive irrigation system extends and radiates from the Big Lost River across the entire INL. Overgrown and barely discernible field scars are also associated with the irrigation features.

Although irrigation projects in the Mud Lake area were successful, irrigation efforts and associated homesteading activities associated with the Big Lost River failed and were essentially abandoned by the mid-1920s. Soil porosity and upstream water use contributed significantly to this failure. In addition to roads and canal systems, artifacts from the 1800s and early 1900s include stagecoach stations and remnants of homesteading activity such as foundations, domestic items, and children's toys that give insight into the daily lives of the early pioneers. Approximately 100 historic archaeological sites have been recorded from this period with hundreds more awaiting identification and recordation. At many of these sites, careful INL CRMO research has enriched the archaeological evidence by the discovery of associated archival materials including official homesteading and irrigation company records, family photographs and documents, and interviews with ancestors of the early pioneers (see Section 6). 


\subsubsection{Arco Naval Proving Ground}

With the outbreak of World War II (WWII), Pocatello, Idaho, was selected as a location to construct an ordnance plant with a mission to reline and test Pacific Fleet naval armament. Shortly after plant construction was completed, the Arco Naval Proving Ground (ANPG) was established on core lands that would eventually become the INL Site about 12 miles east of Arco, 50 miles northwest of Pocatello, and a similar distance west of Idaho Falls, to test the relined guns. Beginning late in 1942, testing began and during the course of the War, all manner of ship weaponry, from anti-aircraft guns firing 3 -in. rounds to the main battleship 16-in. guns were test-fired at the ANPG. The latter fired 2,800-pound test rounds from the Scoville railroad siding (now the Central Facilities Area [CFA]) as far as 20 miles to the north.

After the end of WWII, the ANPG continued its mission to test various kinds of conventional explosive ordnance. The tests were designed to explore storage and transport methods to minimize the potential for sympathetic explosions. Artifacts remaining from the WWII period are concentrated at CFA and in a wide firing fan that extends to the northeast. At CFA, resources include buildings like the brick bungalow that once served as

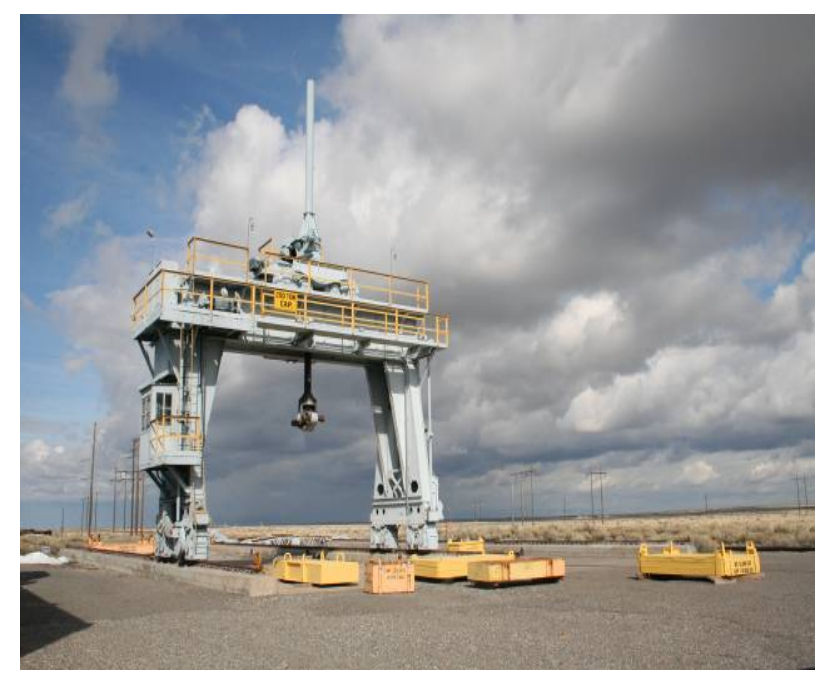

1943 Gantry crane used to unload the guns that were tested at the ANPG during World War II officers' quarters, structures like concrete gun mounts and an 8-ft. thick concussion wall with an observation tower that looms above, equipment like the gantry crane that unloaded all manner of weaponry and ordnance, and a landscape of roads, trees, and flowerbeds. In outlying areas, concrete targets, small observation towers, craters, and unexploded ordnance reflect work activities while discarded domestic items from extensive trash dumps provide unique insight into the everyday life of ordnance workers and their families.

\subsubsection{National Reactor Testing Station}

In 1949, the newly established U.S. Atomic Energy Commission (AEC) selected the ANPG as the location to build and test nuclear reactors. Land transfers between the Department of Defense and the AEC were concluded and the National Reactor Testing Station (NRTS) was established. Later that year, and again in the early 1950s, additional land withdrawals were made to bring the facility close to its current 890 square miles. The purpose of the NRTS was to provide an isolated location where prototype nuclear reactors could be designed, built, and tested. The Site was renamed the Idaho National Engineering Laboratory (INEL) in 1974, and again renamed the Idaho National Engineering and Environmental Laboratory (INEEL) in 1997. In February of 2005 it became the Idaho National Laboratory (DOE-ID 2007).

Since its establishment, 52 "first-of-a kind" reactors and associated support structures have been constructed at the NRTS/INEL/INEEL/INL. Ground-breaking research fundamental to the development of nuclear power generation and nuclear propulsion has been conducted at the nine facilities that remain active today and at several that have undergone decontamination, deactivation, and demolition (DD\&D). In recognition of one part of the vast scientific heritage, Experimental Breeder Reactor I (EBR I) has been recognized as a National Historic Landmark, one of only three landmark buildings in the state of Idaho. Present and future Laboratory missions include the development of the next generation of nuclear 
technology for power reactors, the development and testing of national security technologies, and maintenance and expansion of a multi-program national research laboratory role. To meet these goals, INL Site facilities are being consolidated into three main areas including the Reactor Technology Complex (formerly the Test Reactor Area), the Materials and Fuels Complex (formerly Argonne National

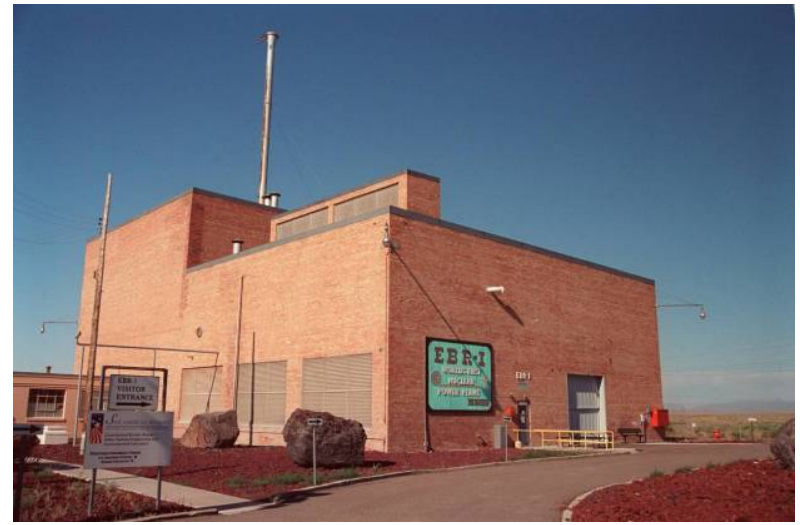

In 1966 President Lyndon Johnson designated Experimental Breeder Reactor I as a National Historic Landmark
Laboratory-West), and the Science and Technology

Campus, a group of offices and laboratories in Idaho Falls. Environmental cleanup, including a significant DD\&D effort, is another important current mission with ongoing effects to historically significant INL properties.

INL building inventories include over 200 properties that are historic, including the EBR I National Historic Landmark and others like the Materials Test Reactor, and are considered to be "signature" properties in the history of the DOE. Most INL buildings have been modified and used for a variety of projects and programs through the years, but still retain historical significance. Indeed, change has been a constant in the architectural history of the Laboratory, perhaps as a partial reflection of the

process of scientific discovery, itself, and the fundamental role that INL facilities have filled in the advancement of nuclear research (Braun 2006). Today, many of the historic buildings have been demolished or are soon to be demolished. In advance of demolition, photographic and documentary evidence are assembled, often in Historic American Engineering Record (HAER) reports, to preserve an archival record of the important scientific achievements that have occurred (see Section 9). The INL CRMO curates many of these records in a newly developed INL Archival Center that is assuming increasing importance for researchers. Indices are also being developed to facilitate access to important archival records stored elsewhere (i.e. photographs, technical reports). Other important nuclear era artifacts include items such as prototype nuclear-powered jet engines, a lead shielded locomotive, and other unique structures and equipment.

\subsubsection{Contemporary Resources and Values}

Tangible evidence of the past such as lithic artifacts, prehistoric campsites, historic trails, homesteads, buildings and structures, and archives such as those described above comprise one form of cultural resources at the INL. A second, equally important form is more ethereal and less easily defined. These resources generally consists of cultural and natural places, landscapes, viewsheds, select natural resources, and sacred areas or objects that have importance for American Indians and others such as the descendents of early pioneers and homesteaders. Ongoing consultation with these groups is facilitating the identification and protection of these less tangible cultural resources.

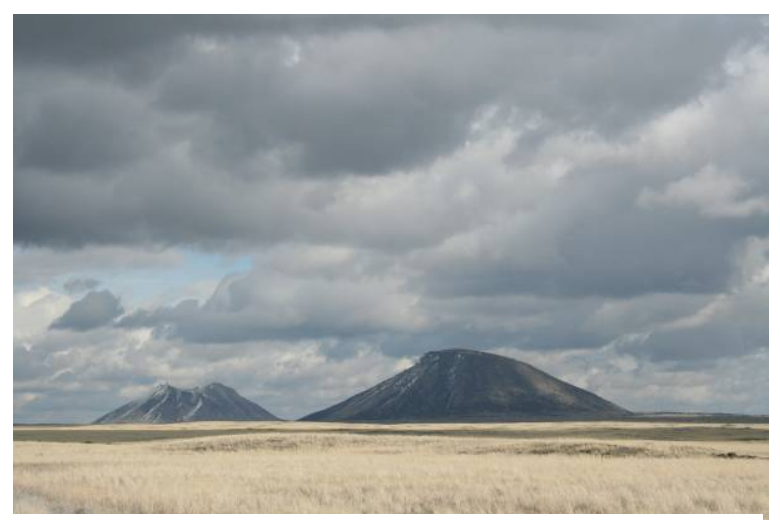

East and Middle Buttes are located near the INL's southern boundary 


\section{PROGRAMMATIC FRAMEWORK}

A suite of federal laws and regulations that direct federal agencies like the DOE to consider cultural resources in their ongoing operations guides all of the activities of the INL CRMO. These requirements are broadly encapsulated in three federal laws: the National Environmental Policy Act of 1969 (NEPA 1969), the Archaeological Resource Protection Act of 1979 (ARPA 1979), and the National Historic Preservation Act of 1966 (NHPA 1966), as amended, and their implementing regulations. Summaries of all are provided in the INL CRMP (DOE-ID 2007).

Some elements of the INL CRMO compliance responsibility are prescriptive, for example the routine completion of archaeological surveys to identify cultural resources that may be impacted by proposed ground disturbance on INL lands or reviews of proposed modifications to INL facilities (NEPA, NHPA Section 106). Other elements allow more latitude, for example the requirement that all federal agencies, including DOE-ID at the INL, assume responsibility for all historic properties under their jurisdiction, not only those lying in the path of proposed development (NHPA Section 110) and requirements for conducting public outreach and education about archaeology (ARPA).

The overall approach to meeting the substantive requirements of the pertinent legal drivers is presented in the INL CRMP (DOE-ID 2007). Reviewed and approved by the Idaho State Historic Preservation Office (SHPO), Advisory Council on Historic Preservation, National Park Service, and Shoshone-Bannock Tribes, this document includes standards for identification, evaluation, and protection of all types of INL cultural resources. Regular updates ensure its continued relevancy. Within the CRMP, historic contexts and research designs have been developed to guide Section 110 activities and public outreach and education. Historical themes such as prehistoric settlement and subsistence, early historic exploration and discovery, fur trapping and trading, emigration, transportation, homesteading and irrigation, agriculture, ranching, ordnance testing, nuclear reactor testing, cold war weapons and military applications, commercial power reactor safety and design, chemical reprocessing, and remediation of waste provide the primary contexts under which research is conducted. For archaeological sites, problem domains such as chronology, settlement and subsistence, cultural relationships, demography, environment, technology, and data recovery techniques are also addressed.

The INL CRMP (DOE-ID 2007) is an efficient means to maintain compliance with regulatory drivers and implement DOE policies and procedures. The tailored and streamlined cultural resource compliance processes developed in the Plan are designed to balance historic preservation with the need to clean up the environment and allow present and future projects to proceed, while maintaining focus on the intent of the regulatory drivers, which is to preserve the important heritage contained within the Site boundaries. In other words, the Plan strives to create a balance between the past, present, and future. Every year, the INL CRMO prepares a summary report describing the tasks completed toward the goals contained within the CRMP. The high level summaries that follow provide stakeholders and interested parties with an opportunity to reflect on progress and provide direct feedback for future activities. This interaction is critical to ensure that the CRM program remains focused on stewardship of INL cultural resources for present and future generations. 


\section{INL CULTURAL RESOURCE PROGRAM PERSONNEL}

The INL CRM program is comprised of three entities: DOE-ID, the INL CRMO, and the Shoshone-Bannock Tribes' DOE Program. DOE-ID's Environmental Technical Support Division takes responsibility for general oversight of CRM activities through a designated Cultural Resources Coordinator. This individual is assisted by DOE-ID's Tribal Liaison Officer from the Public Affairs Office, who in turn has lead responsibility for coordinating communications and interactions with the Shoshone-Bannock Tribes. The Tribal Liaison Officer also manages the DOE-ID funded Tribal DOE Program based at Fort Hall.

DOE-ID entrusts execution of its cultural resource program and policies along with regulatory compliance oversight to the INL CRMO. The

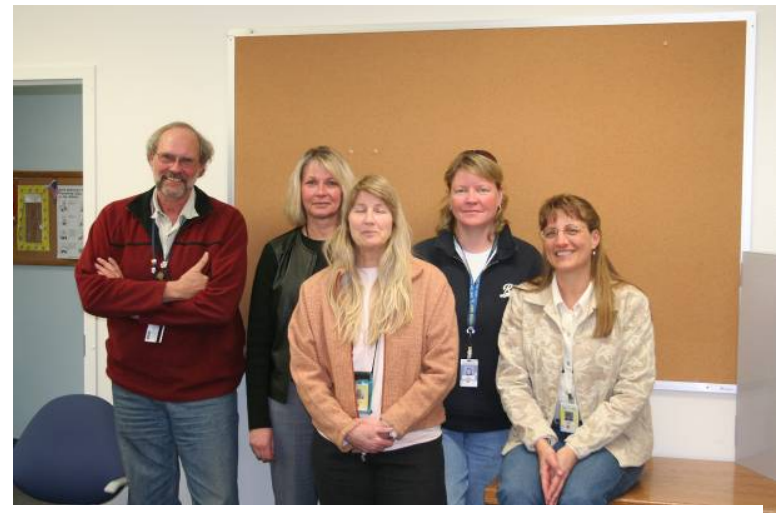

Clayton Marler, Julie Braun, Dino Lowrey, Hollie Gilbert, and Brenda Pace, INL CRMO

CRMO staff is comprised of BEA personnel who are qualified professionals in the fields of archaeology, history, architectural history, historic preservation, and sociology. The described technical capabilities reflect education, experience and training but not necessarily current job function. Shifting funding levels and resources require adaptability and versatility, and some of the work performed by CRMO staff is unrelated to cultural resource management (e.g., borrow source management and geological mapping). CRMO staff also assist other INL contractors (e.g., CWI,

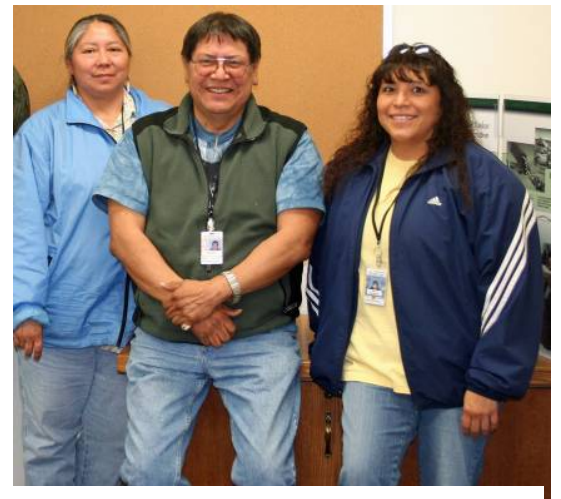

Caroline Boyer Smith, Willie Preacher and LaRae Buckskin, Shoshone Bannock HeTO; (Joetta Buckhouse and Patty Johnson, not shown) BBWI, NRF) in execution of cultural resource compliance for projects at the INL Site.

DOE-ID and the INL CRMO maintain a close cooperative relationship with the Shoshone-Bannock Tribes per a written Agreement in Principle (AIP) (DOE-ID 2002). The Tribal DOE Program is overseen by a Program Director, who has broad responsibilities that include, among other things, implementation of the AIP through oversight of INL environmental programs, transportation safety, and cultural resource management. Technical specialists in the Shoshone-Bannock Heritage Tribal Office (HeTO) interact directly with INL CRMO staff and participate in many activities, providing valuable assistance and a unique holistic perspective that facilitates protection of both tangible and intangible INL cultural resources. 


\section{CULTURAL RESOURCE MANAGEMENT OFFICE ACTIVITIES}

\subsection{Funding}

In general, there are two types of funding that support CRM work at the Site. "Direct" funding is provided by specific projects or programs to support compliance with Section 106 of the NHPA. "Indirect," or overhead funding, is provided to accomplish crosscutting management activities not associated with specific projects and to address the full range of regulatory drivers. In 2005, the DOE-ID let two separate contracts that fundamentally divided work performed at the Site into two distinct entities. The Idaho Completion Project (ICP) focuses solely on cleanup operations, while overall landlord responsibilities, facility operations, and management has coalesced into the Idaho National Laboratory, an organization whose purpose is aligned with current and future research and development missions. In FY 2006, the ICP contractor, CH2M Hill/Washington Group International (CWI), funded approximately 1.7 full-time employees (FTEs) to support cultural resource milestones associated with accelerated cleanup while the INL contractor, Battelle Energy Alliance (BEA), provided indirect funding for approximately 2.2 FTEs (General and Administrative, Overhead) and direct project funding for 0.5 FTEs. The remaining funding (.6 FTE) was for non-CRM related work such as geotechnical graphics and mapping and borrow source management. The balance of this report describes accomplishments resulting from ICP direct, INL direct, and INL indirect CRM funding only.

\subsection{Approach}

Cultural resource management on the INL is a dynamic process with some short-term goals and activities being accomplished each year in support of the overarching management goals of identification, evaluation, and resource protection and preservation as described in the INL CRMP. As specific tasks are accomplished or goals achieved, they might be dropped from the list while others might become ongoing activities. New goals and tasks are added in response to changing conditions at the Site and within the regulatory framework that drives compliance activities, and in consideration of comments and advice from stakeholders.

There are ten long-term goals for the INL CRM program with a variety of ongoing and recurring tasks associated with each goal.

\section{Goal 1: Identify and Manage INL Cultural Resources}

- $\quad$ Task 1. Inventory and record INL cultural resources.

- $\quad$ Task 2. Seek and maintain preservation partners.

- $\quad$ Task 3. Reevaluate and update program requirements.

- $\quad$ Task 4. Maintain program files and records.

- $\quad$ Task 5. Conduct oral histories and interviews.

\section{Goal 2: Evaluate INL Properties for Historic Significance}

- $\quad$ Task 1. Conduct research to develop and update prehistoric and historic contexts required to identify themes and establish the relative importance of specific resources. 
- $\quad$ Task 2. Evaluate INL properties against National Register of Historic Places (NRHP) criteria.

- $\quad$ Task 3. Prepare NRHP nominations and associated documentation.

\section{Goal 3: Monitor the Condition of INL Cultural Resources}

- Task 1. Establish the baseline condition of, and choose monitoring points at select INL cultural resources.

- $\quad$ Task 2. Assess condition of select INL cultural resources, including at a minimum, EBR I, Aviator's Cave, Prickly Cave, and the WERF burial.

\section{Goal 4: Protect INL Cultural Resources}

- $\quad$ Task 1. Participate in legal and regulatory reviews of INL policies and procedures to ensure integration and maximize effectiveness of overall regulatory compliance.

- $\quad$ Task 2. Develop and update historic structures preservation plans.

- $\quad$ Task 3. Respond to the unanticipated discovery of cultural resources.

- Task 4. Review, approve, and archive external investigator permits and oversee subcontracts.

- $\quad$ Task 5. Establish and maintain an INL Archive Center.

- $\quad$ Task 6. Develop and implement specific site protection and stabilization plans, as needed.

\section{Goal 5: INL Artifact Curation}

- $\quad$ Task 1. Prepare pre-1942 artifacts in INL interim storage and associated documentation for accession into an accredited curatorial facility.

- $\quad$ Task 2. Ensure the security of artifacts and associated documentation in interim INL storage.

- $\quad$ Task 3. Review and approve requests for use of INL artifact collections.

- $\quad$ Task 4. Prepare for and participate in an annual inspection of curatorial facilities, as required by DOE-ID.

\section{Goal 6: Stakeholder Involvement/Public Outreach}

- $\quad$ Task 1. Participate in the INL Speakers Bureau, Science Expo, and other educational outreach programs.

- $\quad$ Task 2. Coordinate and conduct public and employee tours of cultural resource sites.

- $\quad$ Task 3. Present information on INL cultural resources and prehistoric and historic contexts.

- $\quad$ Task 4. Host and conduct annual stakeholder meeting/tour to report on previous fiscal year activities and seek input. 
- $\quad$ Task 5. Participate in professional events (i.e., conferences, meetings).

- $\quad$ Task 6. Publish peer-reviewed articles.

\section{Goal 7: Interact with American Indians}

- $\quad$ Task 1. Comply with cultural resource-related stipulations in the Agreement in Principle between DOE-ID and Shoshone-Bannock Tribes.

- $\quad$ Task 2. Participate in monthly Cultural Resource Working Group meetings.

- $\quad$ Task 3. Invite HeTO participation in archaeological fieldwork.

\section{Goal 8: Conduct Work Safely}

- $\quad$ Task 1. Conform to Integrated Safety Management System (ISMS) requirements.

- $\quad$ Task 2. Inspect equipment regularly.

\section{Goal 9: Maintain Professional Qualifications and Relationships}

- $\quad$ Task 1. Identify and attend training to enhance/maintain skills.

- $\quad$ Task 2. Establish and maintain memberships and seek leadership positions in professional societies and organizations,

- $\quad$ Task 3. Interact with other cultural resource professionals (i.e., State Historic Preservation Office, National Park Service, professionals at other DOE labs).

\section{Goal 10: Activities Reports/Plans}

- $\quad$ Task 1. Complete annual report of activities conducted during the previous fiscal year.

- $\quad$ Task 2. Complete annual Department of Interior (DOI) questionnaire for previous fiscal year (Contract Data Requirements List [CDRL] F.45).

- $\quad$ Task 3. Complete annual monitoring report for previous fiscal year (CDRL F. 46).

- $\quad$ Task 4. Complete quarterly reports to Shoshone-Bannock HeTO.

- $\quad$ Task 5. Update INL Cultural Resource Management Plan, as needed (CDRL F.47).

- Task 6. Prepare an NRHP nomination package for a significant INL cultural resource and submit to DOE-ID, as requested (CDRL F.48). 


\subsection{FY 2006 Highlights}

Each year performance measures in the form of specific milestones related to the general activities discussed above are selected to guide work activities and gauge programmatic effectiveness. In FY 2006, the CRMO successfully completed all formal deliverables including the following:

- Annual Site Monitoring Report (INL-CRM 2005b)

- INL input to the annual Secretary of the Interior's Questionnaire on the Federal Archaeology Program (web page for links to these annual reports - https://homer.ornl.gov/nuclearsafety/nsea/oepa/cultural/)

- Annual report on INL CRMO activities (INL-CRM 2005a)

- Report on NHPA Section 110 activities (Marler 2006)

- $\quad$ Final TRA (now known as RTC) Historic American Engineering Record report (Stacey et al. 2006)

- Draft Fuel Reprocessing Complex (located at INTEC) Historic American Engineering Record report (Pace et al. 2006)

Field activities in FY 2006 were dominated by a few large archaeological inventories completed to assess the potential impacts of proposed ground disturbing projects under Section 106 of the NHPA (see Section 9), NHPA Section 110 surveys (see Section 6), and routine monitoring of particularly sensitive localities (see Section 10). Much of the Section 106 work involved areas that had been intensively surveyed for cultural resources many years ago. Archaeological sites originally recorded in these areas were revisited and tribal counterparts were taken to see many for the first time. These projects provided an opportunity for tribal counterparts to share information and express concerns that ultimately help INL CRMO staff to refine a holistic view of cultural resources that is addressed in cultural resource law, regulation, and DOE policy (see Section 8).

Section 110 field surveys in FY 2006 involved the recording of newly discovered resources from both prehistoric and historic time periods and provided opportunities for INL CRMO staff to conduct professionally stimulating research. The diverse inventories and refined classifications resulting from these projects are beneficial to the CRM program as a whole and the resulting publications and presentations at professional conferences enhance the professional standing of the INL.

Preservation of INL's modern history was furthered in FY 2006 by establishment of an INL Archive Center where important archival materials such as photographs, engineered drawings, and key documents will reside and be made available for current and future researchers. Large inventory and assessment projects were also brought to completion

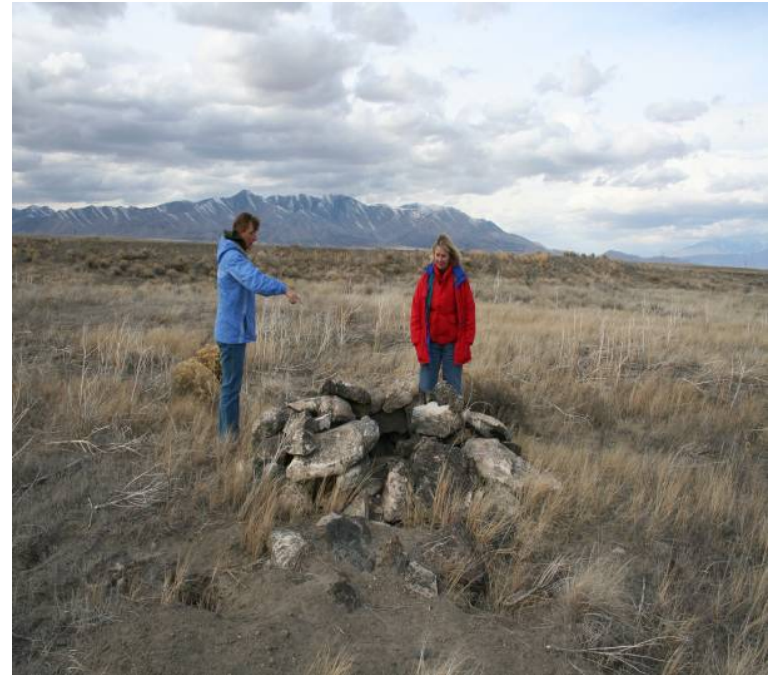

Brenda Pace and Julie Braun investigate a basalt igloo associated with a ca. 1910 canal construction camp for two key INL facilities, the Test Reactor Area (TRA - now known as RTC) and the Fuel Reprocessing Complex located at the facility now known as INTEC, but previously designated as the Chemical 
Processing Plant. Detailed Historic American Engineering Record reports for several of INL's important historic scientific programs and facilities (Test Area North, Waste Calcining Facility, Power Burst Facility, etc.) were also published and distributed to historians and stakeholders (see Section 9).

As in previous years, INL CRMO participation in tours and various educational events proved to be enjoyable for all (see Section 7). Notable events and activities for the year included a well-attended public tour of INL cultural resource locations in celebration of Idaho Archaeology and Historic Preservation Month and INL CRMO information/activity booths hosted at the INL Employee and Family Open House and the public Science and Engineering Expo (see Section 7). 


\section{NHPA SECTION 110 PROJECTS}

Section 110 of the National Historic Preservation Act (NHPA) directs federal agencies to identify, evaluate, and nominate properties for which they have responsibility to the National Register of Historic Places and to manage those properties in a manner that considers their protection and preservation. The purpose of NHPA Section 110 is to provide statutory emphasis as well as intellectual guidance to establish a program whose aim is not only to protect resources but also to achieve enhanced understanding of human history.

In addition to meeting compliance requirements and research goals, a common thread through all of the INL CRMO Section 110 projects is a commitment to partnerships. Developing synergistic relationships with fellow INL scientists along with students and researchers from regional museums and universities enriches thought, creativity, and intellectual rigor. These relationships help clarify the current regionally important research questions, and in return the INL provides a unique, relatively well-protected "outdoor laboratory" and extensive archives with which to seek ways to answer those questions.

The archaeological sites, historic architectural properties, traditional cultural areas, sacred American Indian sites, and natural resources that define the INL landscape are integrated aspects of larger human systems adapted to the high-desert landscape of southeastern Idaho that have been operational for at least the past 13,500 years. CRMO Section 110 projects are selected to address broad questions about how humans have used this landscape, how and why land-use has changed through time, and the role of technology as a means to shape, or simply survive the natural environment. In FY 2006, INL CRMO Section 110 projects included three emphasis areas: examination of Late Holocene rock structures and possible functions, human riparian and marshland adaptations in the high desert, and historic EuroAmerican settlement patterns and site characterization.

\subsection{Prehistoric Rock Structures}

The INL contains a variety of rock structures and alignments including rock cairns of various sizes, small rock circles interpreted as prehistoric hunting blinds, substantial fortifications in ridge-top settings, rock piles associated with historic agricultural efforts, and variously sized rock walls located in playa bottoms. In FY 2006, an effort was initiated to develop a preliminary inventory and classification system for these resources.

The initial focus of this effort was toward a number of Late Holocene archaeological sites that contain impressive rock fortifications located in settings that offer panoramic and/or strategic view sheds. The substantial rock structures present at these sites are not like the smaller hunting blinds typically found in the region. They are significantly larger in both height and extent, occupy very high strategic points on the landscape, and are in close proximity to areas that were intensively occupied. In contrast, the smaller rock rings that do appear to have functioned as hunting blinds are typically located on the slopes of lower ridges with commanding, but limited, views of playas, game trails, or other areas favored by game animals. It is also unusual to find evidence of extensive camping activities near these smaller rock structures.

Research on these types of resources was initiated in FY 2006 in cooperation with Dr. L. S. Henrikson, University of Oregon Museum of Anthropology (Henrikson and Pace 2006) and will continue through FY 2007, culminating in a peer-reviewed publication. In FY 2006, two INL resources were recorded or rerecorded to further the study: "Hellofasite" (10-JF-88) and "Lost Arches." Once remote, 
both of these sites are now located near an area preferred for construction of a proposed new INL Explosive Testing Range (DOE-ID 2006a). Efforts will continue to ensure that these significant resources are not adversely impacted by the new activities (Pace et al. 2006).

"Hellofasite" was originally discovered during a 1984 inventory survey of the INL Grazing Boundary (Miller 1985), by a field crew that was duly impressed by the artifacts and rock structures it contained. The site consists of a dense scatter of artifacts in protected sandy coves along a prominent basalt ridgeline. On the northern edge of the site, a substantial rock enclosure was built on the high northern tip of the basalt ridge with a commanding view northwest to Circular Butte, north over the dry bed of Pleistocene Lake Terreton and up the mouth of Birch Creek Valley, northwest over the Big Lost River in Pioneer Basin and the Lost River Sinks, and westerly to the Buttes. Surface finds include abundant stone debitage, fire-cracked rock and possible hearth features, bone and tooth fragments, scrapers, Elko Cornernotched points, Desert Side-notched points, Cottonwood Triangular points, and Intermountain Ware pottery.

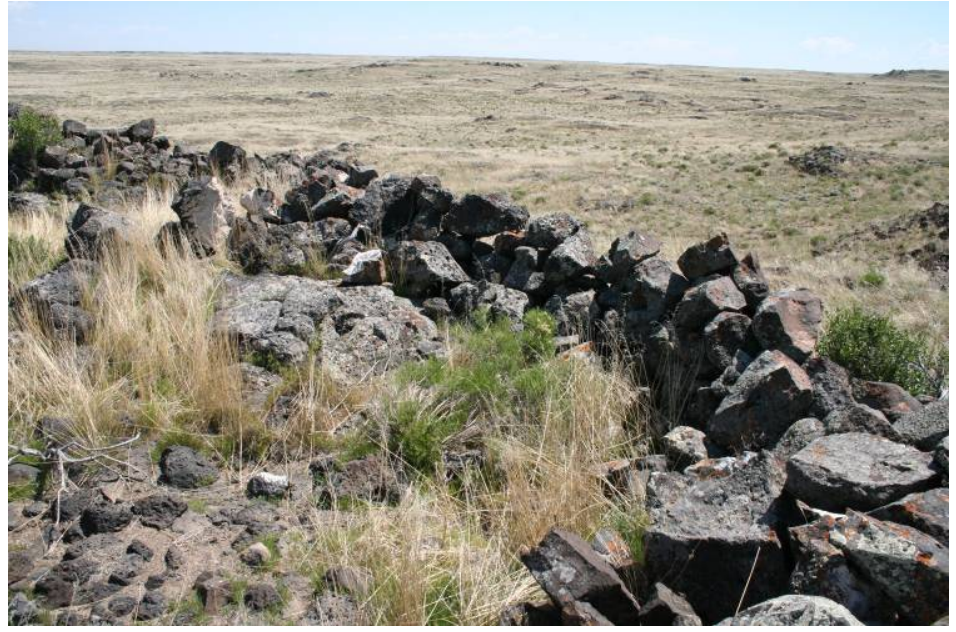

Hellofasite rock enclosure walls

The "Lost Arches" site was discovered during recent surveys of alternate areas for construction of a new INL project (DOE-ID 2006a, Pace et al. 2006). Recording efforts are ongoing and it has not yet been assigned a permanent site number. It is named for a natural arch that has eroded in one of the numerous basalt bedrock outcrops in the site area. Like Hellofasite, Lost Arches occupies a prominent spot on a system of pressure ridges that overlook the Pioneer Basin and the bed of ancient Lake Terreton. Rock walls constructed on the highest point in the site boundary and indeed, the highest point around, ensure a strategic, hidden viewpoint for many miles to the north and west. Both sites also share common assemblages of Late Holocene artifacts dominated by Desert Side-notched arrow points.

Rock fortifications, like those at Hellofasite and Lost Arches, were intentionally placed on strategic vantage points. They may have functioned for refuge or as observation or signaling points during late prehistoric or early historic times when changes in population density, increased movement of peoples, and changing environmental conditions, including a possible increase in moisture (Bright and Davis 1982, Mark and Thackray 2002), appear to have caused changes in local land use (Henrikson and Pace 2006). Research into these compelling topics will continue in FY 2007 in cooperation with regional partners from the University of Oregon, California State University, Idaho State University, the Bureau of Land Management, and Craters of the Moon National Monument. 


\subsection{Prehistoric River and Marshland Adaptations}

Understanding how natural environmental systems have changed through time and how human systems adapt to those changes, either by changing lifestyles or by changing the environment itself (intentional or inadvertent) is becoming increasingly important in the $21^{\text {st }}$ Century. This ongoing project is intended to explore specific human adaptations to relatively resource-rich aquatic environments in the eastern Snake River Plain high desert. Of particular interest is understanding if, and how land and resource-use may have changed through time in response to changing environmental conditions. Previous research (Marler 2004) has shown statistically significant changes in archaeological site distribution from the Late Pleistocene to the Early Holocene. Multiple, likely interrelated explanations for these changes exist but certainly Holocene warming trends and declining effective atmospheric moisture played major roles. Long-term goals include efforts to determine if additional patterned changes can be discerned from the archaeological record throughout the Holocene and reciprocally, to explore the extent to which archaeological site distribution data can help us understand changing paleo-environments.

In addition to research goals, this project is intended serve as a training opportunity for students, through collaborative arrangements with regional universities. In FY 2006, Idaho State University Anthropology graduate students were recruited as part of a field methods class to help build on work conducted in 2004 and 2005 that targeted the extreme northern reaches of the Big Lost River as well as portions of the Lake Terreton shoreline near the eastern INL boundary. Lake Terreton was a shallow Pleistocene lake that once spread over hundreds of square kilometers, including approximately $233 \mathrm{~km}^{2}$ of the INL (Butler 1970; Gianniny et al 2002). In 2006 portions of the Pleistocene Lake Terreton shoreline near the Big Lost River Sinks were surveyed along

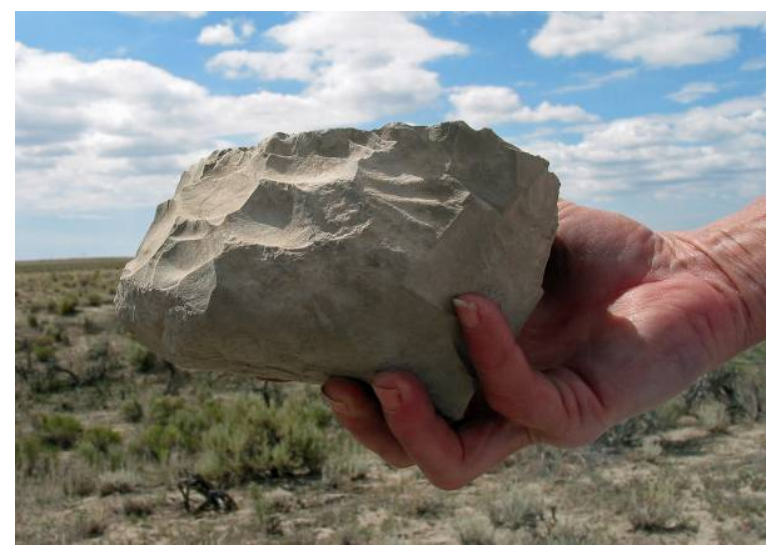

Large "chopping" tool found along the northern reaches of the Big Lost River

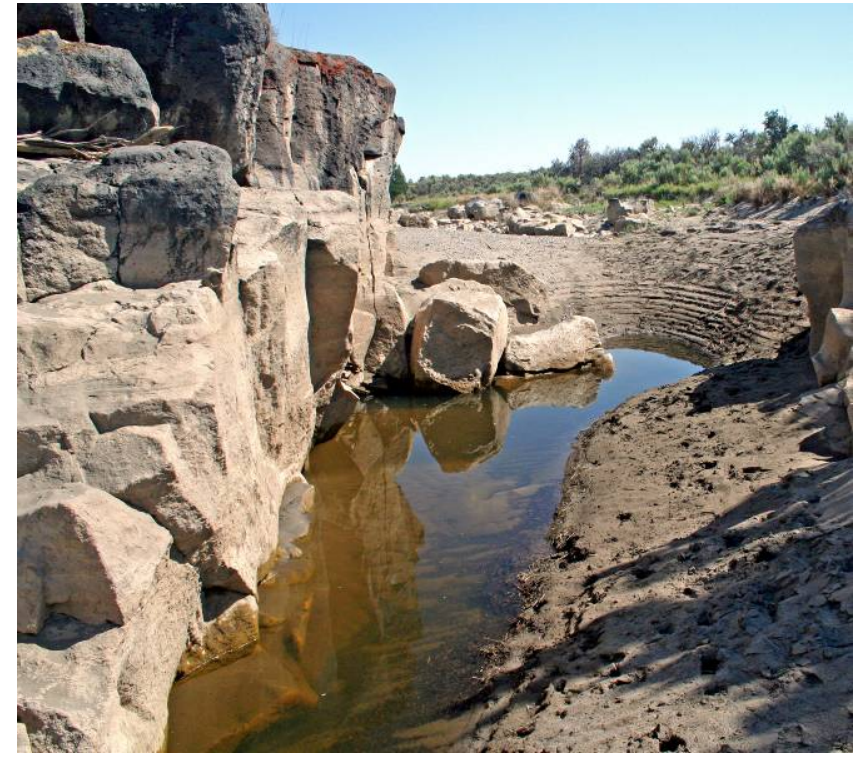

Big Lost River in early July. Pools such as this would have been an important resource in a desert environment during dry summer months with lands adjacent to the Big Lost River Channel farther to the south near the RWMC. One hundred fifty six acres were intensively surveyed and 27 cultural resources ranging in age from a ca. 12,900 year-old isolated Folsom point fragment to early $20^{\text {th }}$ century sites, were recorded. Ultimately these data will be combined with information from previous Section 110 surveys as well as relevant archived data from past INL surveys in GIS format to explore possible changes in land-use through time and to help design future survey work.

In addition to site distribution studies, long term research goals include comparative studies of site assemblages to determine, among other things, if there is a distinctive "wetland toolkit." For example, are 
ground stone tools suitable for plant or seed processing more commonly found along playa or river shorelines than elsewhere? Intuitively the answer is "yes" but additional data are needed to confirm this. Eventually the research focus will also be expanded to include exploration of the subsistence role that the multitude of small playas that exist on the INL may have played. Finally, future plans include a pilot project in association with various organizations to develop an educational program intended for younger students as well as interested adults. Relevant locations will be selected for intensive survey and participants will be trained in field survey and site recordation techniques.

\subsection{Historic Homesteads}

Historic archaeology undertaken by INL CRMO staff involves fieldwork of two very different types. One takes place among rock foundations, crumbling cisterns, domestic trash, and other material remains left on the desert landscape. The other takes investigators to regional archives, often housed in the basements and back rooms of local county seats or state offices, or in microfiche collections housed at local libraries. When investigators successfully tap both sources of information, a rich and often detailed description of this period of INL history, complete with the real human stories, is possible.

Recently, INL CRMO staff has initiated a systematic investigation of some local archives to gather new information on homesteading and agricultural development of INL lands from ca 1880 1920. The preliminary results of this effort suggest that several hundred homesteads once existed upon the INL landscape. Irrigation records revealed over 650 homestead filings under the Carey Land Act alone. Historic sites at the INL recorded as homesteads, contain evident features such as foundations, cisterns and ditches, while sites containing less descriptive artifacts such as cans and broken glass have been interpreted as simple trash scatters. During FY 2006, new research was initiated in order to compare the results of archival research with the previously recorded trash scatters to determine if some might be homesteads. Ultimately, the goal of this research is to develop criteria for correctly classifying and recording INL historic sites in the future.

An initial literature search identified 51 candidate sites for reevaluation. These sites were selected based on

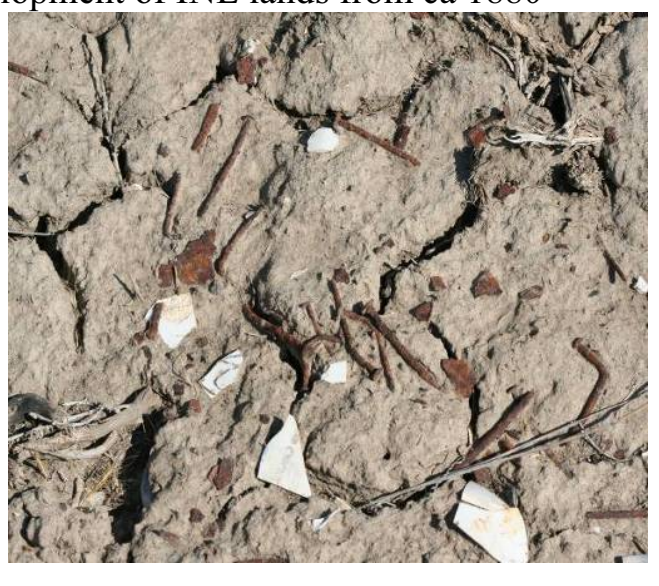

Typical scatter of nails and ceramic shards from an INL historic site

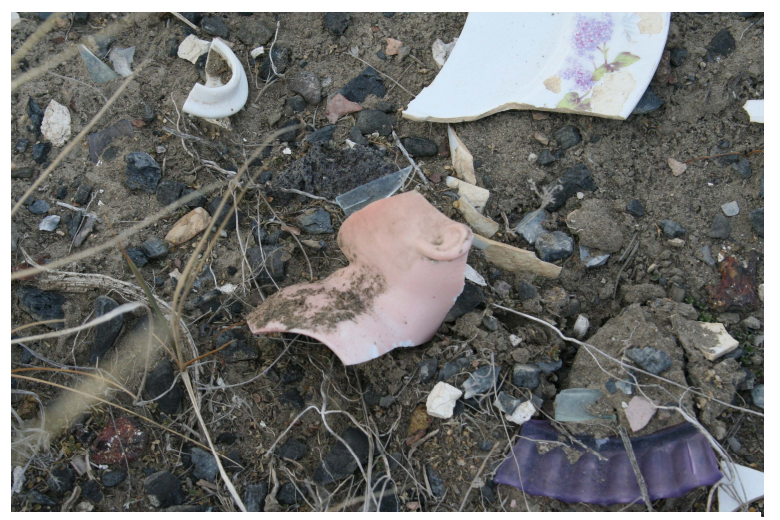

A porcelain doll fragment lies among other domestic artifacts amounts and types of artifacts and features previously noted. Formerly recorded site types included trash dumps, can scatters, campsites, sheep camps, probable homesteads, and homesteads. Seven of these locations were visited and reassessed in FY 2006. Preliminary findings indicate that artifacts associated with homesteads include a large number of used/extracted nails, window pane glass, and molded and lumbered wood. These artifacts can be indicative of a homestead even when structural remains (e.g., foundations, cisterns) are not present. Larger domestic artifacts such as stoves and stove piping as well as dense scatters of cans and domestic glass might also indicate the location of a homestead. Continuation of this research is planned for FY 2007. 
In collaboration with the INL Summer Internship Program, the CRMO took this research a step further and completed intensive field and archival investigations of one particular locale known as the Richards homestead. Based on this research, it is believed that the Richards family lived upon the INL landscape longer than any other known homesteader from 1884 to 1902, raising a variety of crops and livestock. The extensive artifact assemblage left behind by the Richards adds to our knowledge of INL homesteads and the people who lived there, and will further assist with developing criteria for historic site recordation. Since regional histories do not end at the INL border, the location of graves belonging to the Richards family located just over $1 / 2$ mile from the INL boundary could possibly lead to future collaborations with private and other federal landowners.

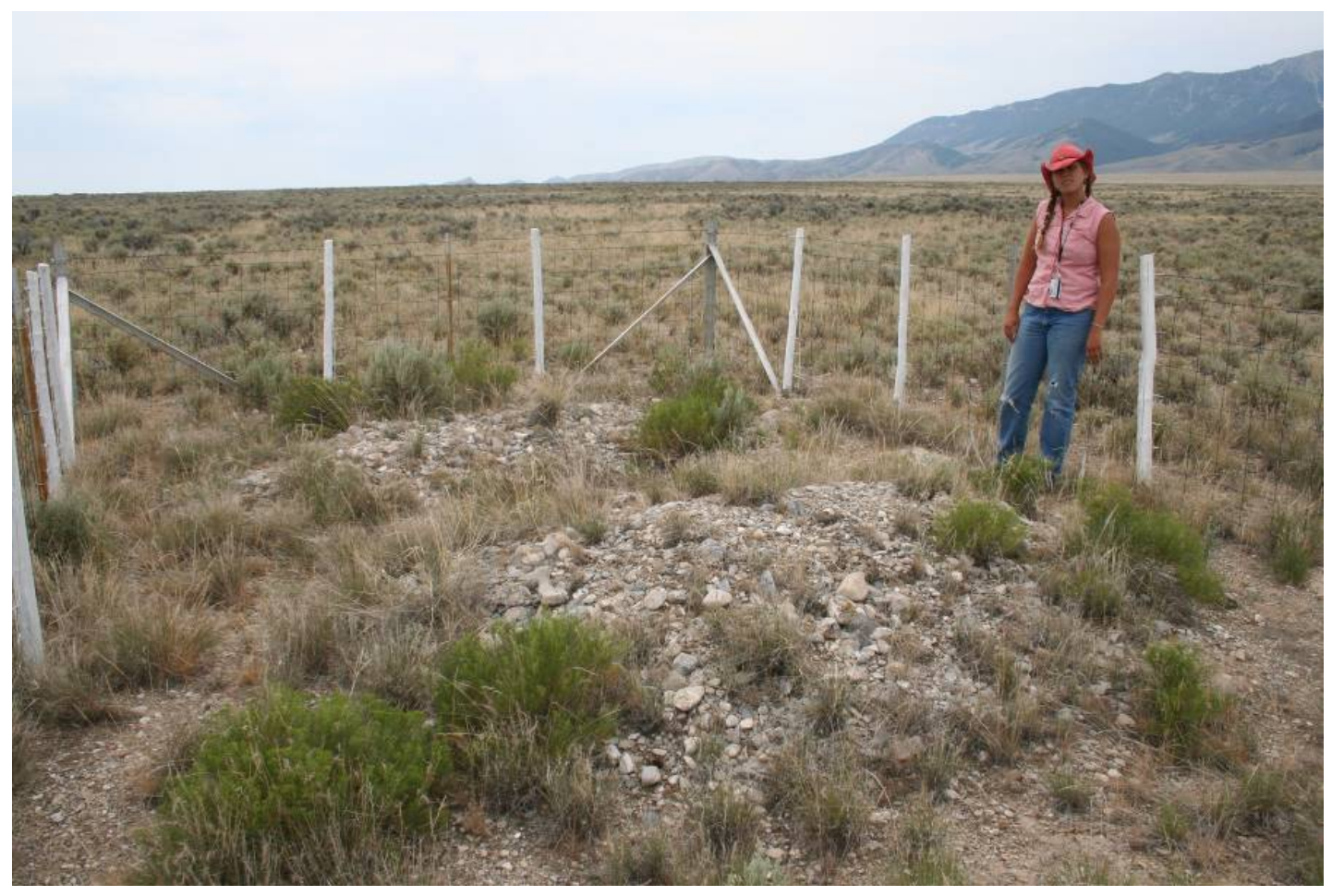

Kathryn Myers, INL CRMO summer intern, at the Richards' family graves located just off the INL 


\section{STAKEHOLDER AND PUBLIC OUTREACH}

As a federal agency, DOE-ID is required by a number of statutes, most importantly the NHPA, to manage INL cultural resources in a spirit of stewardship for the citizens of the United States and to provide those citizens an opportunity to become involved in the cultural resource management process. Systematic planning for public participation in INL cultural resource management helps to ensure that such participation takes place routinely and productively and that public interests regarding resource preservation and interpretation are considered as the Laboratory executes its primary missions. The list of potential stakeholders is as varied as the resources themselves, including such diverse groups as local historical societies, museum associations, Oregon Trail enthusiasts, INL retirees, historical and scientific researchers, American Indian tribes, and the general public. Because of the government-to-government relationship between DOE-ID and the Shoshone-Bannock Tribes, tribal outreach and participation are discussed separately in Section 8.

During FY 2006, communication strategies were implemented through a variety of tours, presentations, publications, educational events and participation in local and regional archaeological and historic preservation activities. All are briefly outlined in sections to follow.

\subsection{Tours}

Tours have proven to be one of the most effective and enjoyable public outreach tools for INL CRMO staff and participants alike. In 2006, nine tours to INL cultural resource locations were provided to such diverse groups as Idaho Senator Mike Crapo's staff, the Idaho State Superintendent of Schools and members of her staff, the INL Citizen's Advisory Board, the BEA Leadership Management Team (LMT) and their spouses, BEA Human Resources staff, the Museum of Idaho Summer Science Camp teachers and students, and the Idaho Falls Community Leadership team. Finally, the annual public tour was conducted in May as a part of Idaho Archaeology and Historic Preservation Month activities.

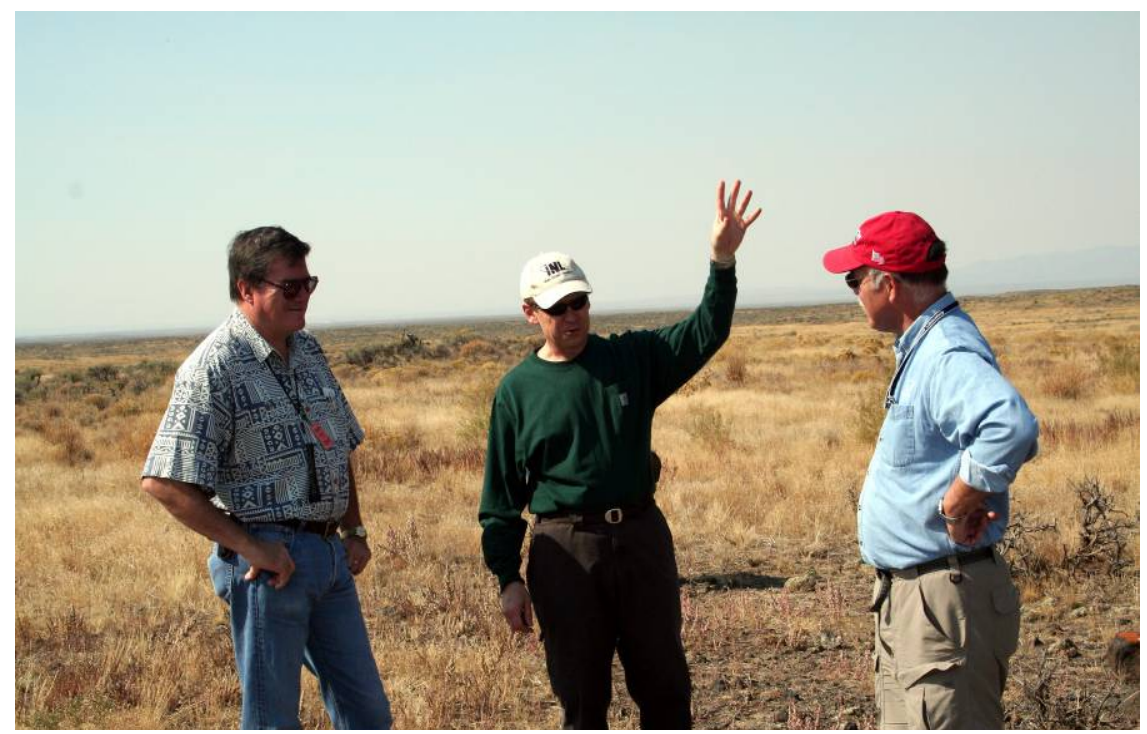

Bill Rogers, John Grossenbacher and Jack Lance from the BEA

Leadership Management Team touring Aviator's Cave 


\subsection{Presentations and Publications}

INL CRMO staff visited schools, community groups, and INL organizations as part of an ongoing program to share information about INL cultural resource management activities as well as knowledge about the cultural resources themselves. In FY 2006, hundreds of interested INL employees and members of the public were reached through these efforts. Among the presentations provided in FY 2006, two events stand out due to the number of people reached and the enthusiastic participation of the entire CRMO staff. The first event was an INL Employee and Family Open House held in August. INL CRMO staff hosted a fun, hands-on informational booth on the lawn at CFA for this event that was especially popular with children. Walking tours featuring buildings and other landscape features associated with WWII and the ANPG were also offered. In September, CRMO staff participated in the "INL Science and Engineering Expo" an annual event that draws thousands of students in grades 6 8 , parents, and teachers with the intent to stimulate interest in science, particularly among young students. Informational booths and displays provided interactive opportunities in virtually all scientific disciplines. The INL CRMO figured prominently in this year's event with informational posters and displays, along with interactive training in American Indian technologies and a large wall panel providing hands-on experience in creating "rock art." Over 2,500 students attended the event, which was judged by organizers and participants alike, as a great success.

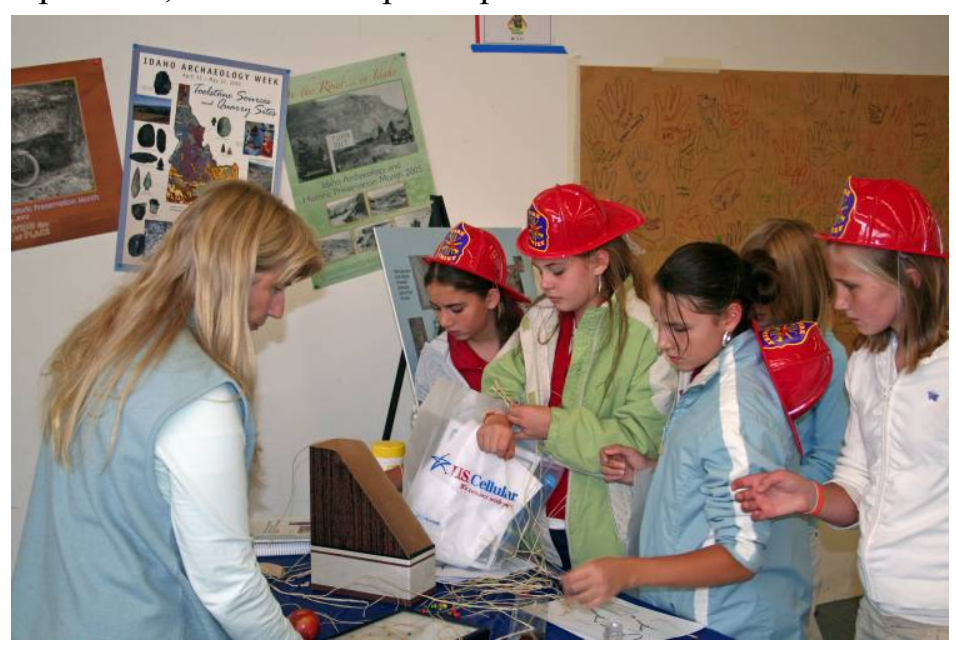

Dino Lowrey interacting with students at the 2006 Science and Engineering Expo

In addition to community

outreach, INL CRMO staff also actively participated in professional activities in FY 2006. In this context, individual CRMO staff research projects were presented at national and regional conferences such as the 19th Annual Symposium on the Application of Geophysics to Engineering and Environmental Problems in Bellevue, WA, and the Great Rift Science Symposium in Pocatello, ID. Proceedings from both of these conferences are being published in FY 2007. Other FY 2006 publications included a wide variety of technical reports, including Historic American Engineering Record (HAER) reports for complexes slated for DD\&D, archaeological survey reports, and program status reports such as the annual report for FY 2005 monitoring activities. A notable external publication was "Change as an Historic Feature in the Preservation of Scientific and Technical Facilities" (Braun 2006).

\subsection{Professional Associations}

INL CRMO staff members individually conduct a variety of professional activities and serve in numerous capacities in local, regional, and national cultural resource organizations. For example, individual memberships are maintained in various professional organizations such as the Society for American Archaeology, the Society for Historical Archaeology, the Society for Industrial Archaeology, the Idaho State Historical Society, the Idaho Professional Archaeological Council, the Idaho Archaeological Society, the Idaho Falls Historic Preservation Commission, and the Bonneville County Historical Society/Museum of Idaho. CRMO staff complete the majority of these efforts individually, on their own time. 
In addition to general memberships, INL CRMO staff members have also been appointed, invited, and/or elected to positions in several professional organizations, including several leadership roles:

- $\quad$ Chair, Museum of Idaho Board

- Chair, Idaho Falls Historic Preservation Commission

- $\quad$ Registered Professional Archaeologist

- Charter Member, Idaho Professional Archaeological Council

- Member, Idaho Falls Historic Preservation Commission

- $\quad$ Member, Idaho Historic Sites Review Board

- $\quad$ Member, Preservation Action National Board

- $\quad$ Member, DOE-HQ Historic Preservation Executive Committee

- $\quad$ Member, Bureau of Land Management Resource Advisory Council

- $\quad$ Adjunct Faculty, Goucher College

- $\quad$ Adjunct Faculty, Idaho State University

\subsection{Preservation Partnerships}

The INL CRMO is involved in a variety of productive partnerships with federal and state agencies, community organizations, and Universities, and staff members often volunteer their time to support research and public outreach activities. The reciprocal relationships developed through these efforts enhance INL CRMO abilities and help to maintain a network of professional contacts of value to the conduct of CRM on the INL.

In FY 2006, one far-reaching new effort was initiated with the Idaho Department of Transportation (ITD). The focus of this project was the Big Lost River Rest Area, a public facility located within the boundaries of the INL on Highway 20/26 along the banks of the River. Personnel from the INL CRMO and BEA and CWI Public Affairs, ecologists from another DOE-ID contractor, and ITD personnel worked together to design interpretive signage that will be installed during a major rehabilitation effort at the Rest Area in FY 2007. When the rehabilitation is complete, six visually striking signs covering local geology, ecology, archaeology, history and current INL missions will provide a compelling educational opportunity for travelers through the region.

Also in FY 2006, in cooperation with the State Historic Preservation Office, the City of Twin Falls, and the Idaho Archaeological Society, CRMO staff

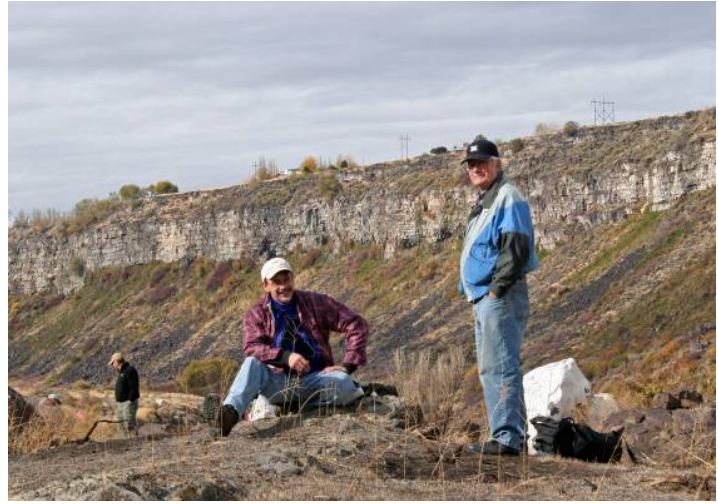

Twin Falls survey volunteers Mike Faulkner, contractor archaeologist, and Gene Titmu, world-renowned lithic specialist. participated in archaeological surveys on land owned by the city and slated for development as a municipal golf course. The land is located at the bottom of the 
Snake River Canyon near Auger Falls and adjacent to the Snake River. A number of prehistoric and historic artifacts and sites were encountered and documented during the course of the project.

The INL CRMO also periodically partners with the Oregon and California Trail Association (OCTA) and the Bureau of Land Management to perform tours and sign maintenance along Goodale's Cutoff of the Oregon Trail, which passes through the southwestern corner of the Laboratory. In October of FY 2006, while performing Trail marker maintenance, a previously suspected portion of the Trail connecting northern and southern routes (both on the INL) was verified and marked.

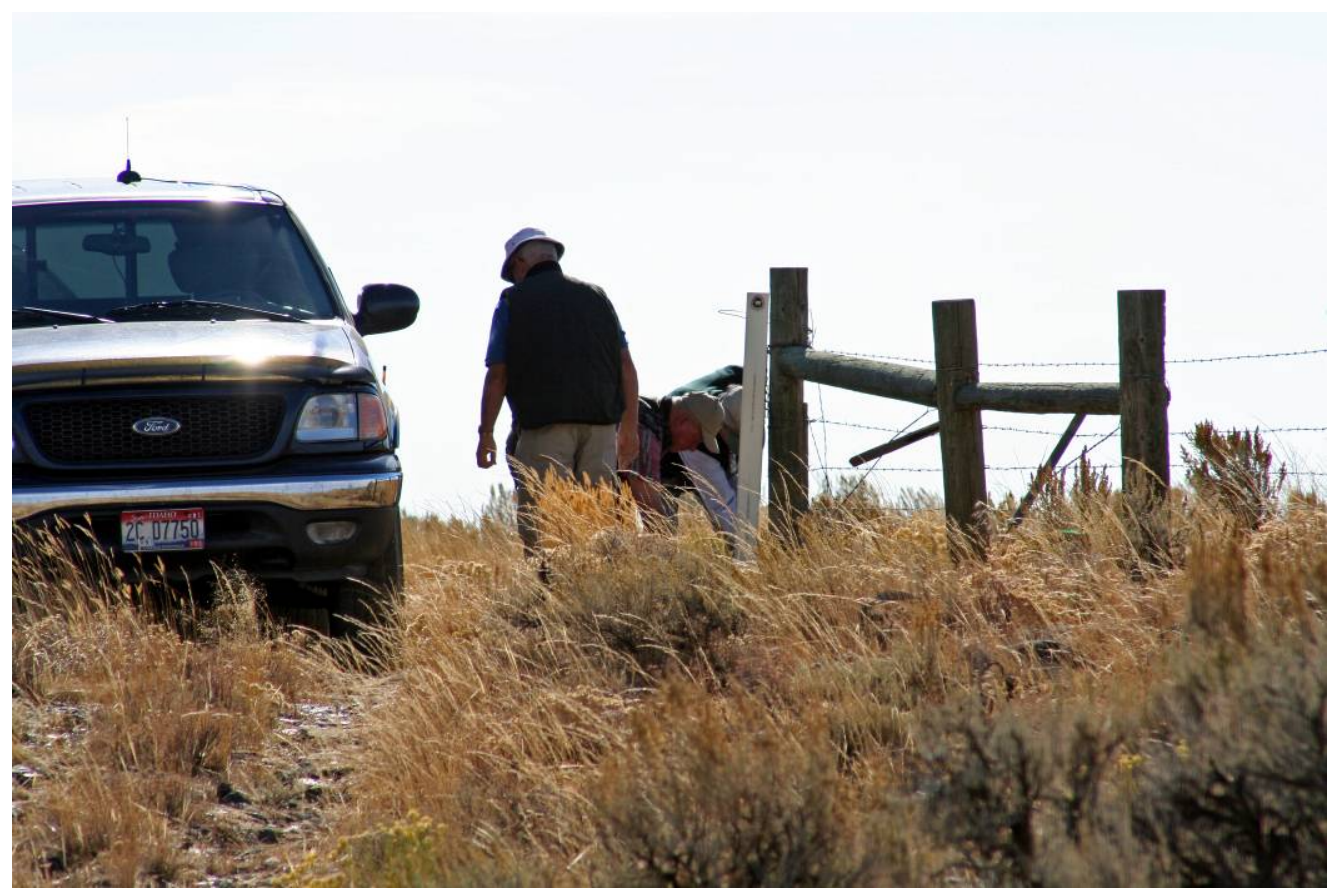

OCTA members perform trail marker maintenance along Goodale's Cutoff of the Oregon Trail 


\section{AMERICAN INDIAN PARTICIPATION}

As a federal agency, DOE-ID recognizes its trust responsibility to the Shoshone-Bannock Tribes and in the spirit of that responsibility has entered into an Agreement in Principle (AIP) with them. The AIP defines working relationships between the Shoshone-Bannock Tribes and DOE-ID and fosters a mutual understanding and commitment to facilitate confidence that activities being conducted at the INL protect health, safety, and the environment, including cultural resources of importance to the Tribes. To aid with implementing cultural resource aspects of the AIP, a Cultural Resources Working Group (CRWG) comprised of representatives from the Shoshone-Bannock HeTO, DOE-ID, and the INL CRMO was established in 1993. Regular CRWG meetings enable issues and opportunities to be addressed in an environment of mutual respect and learning. Tribal input is sought for new and ongoing projects and a standing invitation is extended to comment on, visit, observe, and/or assist in INL CRMO field activities. The holistic view of cultural resources and cooperative spirit encouraged in this group are designed to enhance understanding and appreciation of all types of cultural resources, both within the INL community and the Tribes. For more detail on the relationship between the INL and the Tribes, and detailed working procedures, see Appendix B of the INL CRMP (DOE-ID 2007).

During FY 2006 the CRMO staff participated in all scheduled CRWG meetings and HeTO staff was otherwise informed of INL activities pertinent to cultural resources through preparation and transmittal of quarterly activity reports. HeTO staff also regularly participated in NHPA Section 106 and 110 archaeological surveys and resource monitoring. In these projects, tribal partners from the $\mathrm{HeTO}$ are welcome additions to field crews and their participation helps to expedite fieldwork

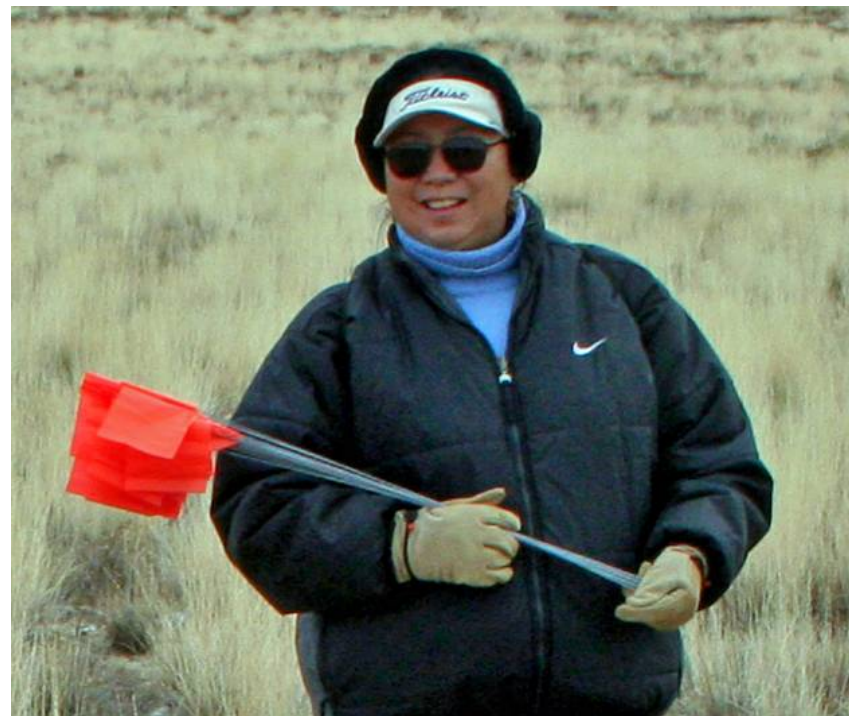

HeTO Director Carolyn Smith assists with monitoring and site re-location work related to a proposed new road completion while also providing opportunities to express thoughts and ideas that go beyond the "stones and bones" of archaeology and into the more holistic concept of cultural resources as required by law and supported by the CRWG. 


\section{NHPA SECTION 106 PROJECT REVIEWS}

The INL is an active facility where thousands of work orders for projects ranging from lawn care to new facility construction are processed each year. Detailed procedures are in place to evaluate the environmental consequences of all activities, large or small. Under company procedures and the INL CRMP, cultural resource reviews are an integral part of the environmental review process and are completed to assess impacts to all cultural resources and to develop recommendations for protection and/or mitigation, when necessary. The goal of the cultural resource review is to determine if the proposed project will affect properties that are eligible for the National Register, if they are Category 1, 2, 3 , or Signature properties based on their relative historic importance, and determine appropriate levels of standard mitigation and/or consultation necessary to establish new mitigation measures, as outlined in the INL CRMP. The process used to make this determination includes archive and record searches and survey.

A review is prompted whenever a project is proposed that meets one or more of the following basic thresholds:

- Ground disturbance outside the boundaries of fenced INL facility areas or more than 50 feet from existing buildings or landscaped areas in unfenced areas

- Ground disturbance within or around the former Power Burst Facility (PBF), now designated as the Critical Infrastructure Test Range Complex (CITRC)

- Activities within known or suspected zones of American Indian sensitivity and/or high archaeological resource density

- Demolition, major structural or landscape modification, permanent closure of extant buildings and structures, and/or removal of original equipment, features, or records

- $\quad$ Activities that may affect the Experimental Breeder Reactor I National Historic Landmark building and grounds

FY-2006 reviews for projects affecting historic architectural resources are summarized in Section 9.1. Non-architectural project reviews are presented in Section 9.2.

\subsection{Historic Architectural Reviews}

The INL contains various property types that are elements of, or have features that contribute to, the overall landscape and understanding of the INL's recent World War II and pioneering nuclear history (1942 - 1970). As in FY 2005, the primary focus of FY 2006 project reviews was on the removal or demolition of historic properties and consolidation of INL facilities to three campus areas. Due to the nature of the cleanup work and that INL remains an active scientific and technical facility; such activities have impacted, or will impact, historic INL architectural properties (i.e. buildings, structures, equipment, original program and project data).

Seventeen project reviews were conducted in FY 2006 for proposed activities that involved twentyone properties, of which six were completely removed through DD\&D. Although consultation was initiated for some of these properties in prior years, the CRMO staff provided the history and results of this consultation to DOE-ID and contractor project managers, advised them on whether or not compliance had been achieved in the cases where mitigation was required, and completed or oversaw completion of 
mitigation activities, when necessary. In the FY 2006 review process, three properties were exempted from the cultural resource review process, one was evaluated as not historic, and seventeen were evaluated as historic (Table 1). For those determined to be historic, mitigation was completed or is in the process of being completed following direction outlined in the INL CRMP or through stipulations contained in existing Memoranda of Agreement with the Idaho SHPO.

Table 1. Historic architectural project reviews completed in FY 2006.

\begin{tabular}{|c|c|c|c|}
\hline $\begin{array}{l}\text { Project } \\
\text { Number }\end{array}$ & Project Name & $\begin{array}{l}\text { Property } \\
\text { Category }\end{array}$ & Review Status \\
\hline 06-01 & $\begin{array}{l}\text { Removal of PER-706 Evaporation } \\
\text { Tank }\end{array}$ & Exempt & PA-Exempt Property \\
\hline $06-02$ & $\begin{array}{l}\text { Modifications to MFC Bldg. } 774 \text { for } \\
\text { Protective Force Consolidation } \\
\text { Support }\end{array}$ & Category 2; eligible & 2004 PA; no adverse effect \\
\hline $06-03$ & $\begin{array}{l}\text { Maintenance of Stream Gauging } \\
\text { Sites at the INL }\end{array}$ & Exempt & 2004 PA-Exempt Property \\
\hline $06-04$ & CPP-603 cold, dark, dry & Category 2; eligible & $\begin{array}{l}\text { Eligible; } 1998 \text { MOA; } 2004 \\
\text { PA' mitigation in progress }\end{array}$ \\
\hline $06-05$ & $\begin{array}{l}\text { Relocation of TAN Shielded } \\
\text { Locomotive to EBR I }\end{array}$ & $\begin{array}{l}\text { Signature Property; } \\
\text { eligible }\end{array}$ & SHPO and NPS concurrence \\
\hline $06-06$ & CF-643 Trailer removal & Exempt & PA-Exempt Property \\
\hline 06-07 & $\begin{array}{l}\text { CF-603 Autopsy/Surgical Room and } \\
\text { Contents }\end{array}$ & $\begin{array}{l}\text { Building ineligible; } \\
\text { surgical table } \\
\text { eligible }\end{array}$ & $\begin{array}{l}\text { SHPO and NPS } \\
\text { concurrence; table } \\
\text { dismantled and relocated to } \\
\text { interim storage in CF- } 633\end{array}$ \\
\hline $06-08$ & TAN-630 demolition & $\begin{array}{l}\text { Signature property; } \\
\text { eligible }\end{array}$ & $\begin{array}{l}\text { Consultation completed; } \\
\text { MOA in place; mitigation } \\
\text { completed }\end{array}$ \\
\hline 06-09 & TRA-603 (MTR) demolition & $\begin{array}{l}\text { Signature property; } \\
\text { eligible }\end{array}$ & $\begin{array}{l}\text { Eligible; mitigation } \\
\text { completed }\end{array}$ \\
\hline $06-10$ & TAN-607 Hot Shop demolition & $\begin{array}{l}\text { Signature property; } \\
\text { eligible }\end{array}$ & $\begin{array}{l}\text { Eligible; LOFT and MTR } \\
\text { MOA; mitigation completed }\end{array}$ \\
\hline $06-11$ & $\begin{array}{l}\text { TAN-633 Hot Cell Annex } \\
\text { demolition }\end{array}$ & Category 2; eligible & $\mathrm{PA}$ - mitigation completed \\
\hline $06-12$ & $\begin{array}{l}\text { TAN-666 Radioactive Liquid Waste } \\
\text { Transfer and Storage building }\end{array}$ & Not eligible & Complete \\
\hline
\end{tabular}




\begin{tabular}{|l|l|l|l|}
\hline $\begin{array}{c}\text { Project } \\
\text { Number }\end{array}$ & \multicolumn{1}{|c|}{ Project Name } & \multicolumn{1}{|c|}{$\begin{array}{c}\text { Property } \\
\text { Category }\end{array}$} & \multicolumn{1}{c|}{ Review Status } \\
\hline $06-13$ & TRA-643 ETR Compressor Building & Category 2; eligible & PA-mitigation completed \\
\hline $06-14$ & $\begin{array}{l}\text { CPP-651 temporary ducting, } \\
\text { equipment, and a new door to room } \\
107\end{array}$ & Category 2; eligible & No adverse impact \\
\hline $06-15$ & $\begin{array}{l}\text { INTEC - CPP-601 PEW Isolation } \\
\text { and Reroute }\end{array}$ & $\begin{array}{l}\text { Signature property; } \\
\text { eligible }\end{array}$ & $\begin{array}{l}\text { 1998 MOA; 2004 PA; } \\
\text { mitigation in progress }\end{array}$ \\
\hline $06-16$ & MFC glove box project & Category 2; eligible & $\begin{array}{l}\text { No adverse impact; } \\
\text { complete }\end{array}$ \\
\hline $06-17$ & CFA-606, 607, 613, 632, 633 & $\begin{array}{l}\text { Signature } \\
\text { Properties }\end{array}$ & $\begin{array}{l}\text { SHPO concurrence, eligible; } \\
\text { physical preservation } \\
\text { recommended }\end{array}$ \\
\hline
\end{tabular}

Mitigation activities conducted in FY 2006, included the completion of a final HAER report for the reactor testing program at the Test Reactor Area, now known as Reactor Test Complex (Materials Testing Reactor and Engineering Test Reactor) (Stacey et al. 2006). This program and the reactors built to support it are among INL's "signature" nuclear properties. FY 2006 also saw completion of a final draft of research conducted to support a HAER report for fuel reprocessing facilities at the Chemical Processing Plant, now known as the Idaho Nuclear Technology and Engineering Center (Pace et al. 2006). The final HAER report for this program will be published and distributed in FY 2007. Finally, research on other historically significant INL facilities was also published in five individual HAER reports as follows:

- $\quad$ Advanced Reentry Vehicle Fuzing System Facility, HAER No. ID-33-B (Stacey et al. 1997a)

- $\quad$ Old Waste Calcining Facility, HAER No. ID-33-C, (Stacey et al. 1997b)

- $\quad$ Power Burst Facility and SPERT I, HAER No. ID-33-F, (Stacey et al. 2005)

- $\quad$ Test Area North, HAER No. ID-33-E (Stacey et al. 2004)

- $\quad$ Test Area North Hangar, HAER No. ID-33-A (Stacey et al. 1994)

INL HAER reports are archived among other significant scientific documents and manuscripts in permanent collections at the U. S. Library of Congress. They are also distributed to a wide variety of organizations and individuals (i.e., professional historians and colleagues in the DOE complex, universities with nuclear programs, politicians, tribes, and local libraries).

Other mitigation activities in FY 2006 included the relocation of the Engineering Test Reactor Sodium Loop control panels from the reactor building to temporary storage. Eventually these unique artifacts will be included in an interpretive display that documents INL's nationally significant reactor testing program. The INL CRMO also led an effort to provide $\$ 25,000$ to the Idaho Heritage Trust for 
use in training students and select INL personnel in activities such as preservation techniques and ARPA enforcement. Due to popular demand, arrangements were also made for a second printing of the INL's $50^{\text {th }}$ anniversary publication, "Proving the Principle: a History of the Idaho National Engineering and Environmental Laboratory, 1949-1999” (Stacey 2000). A final mitigation project involved the Big Lost

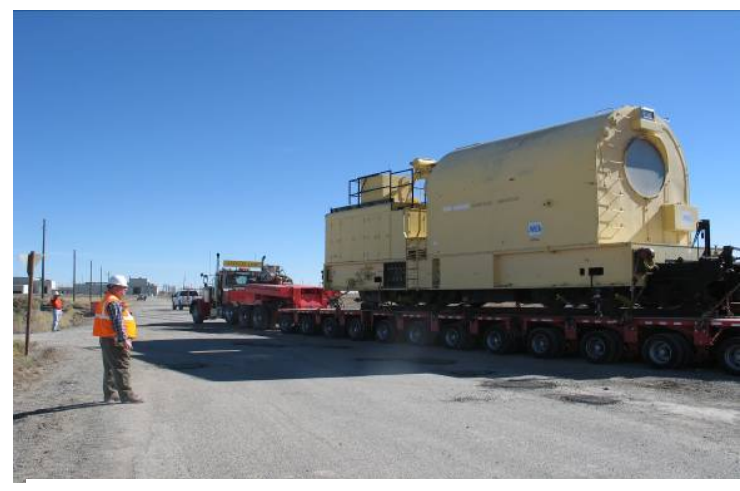

ca. 1954 Shielded Locomotive in transit from INL Test Area North to permanent display at EBR I

River Rest Area signage project discussed in Section 7.

Consultation with the Idaho SHPO and National Park Service in FY 2006 led to the retention of several buildings and structures at the Central Facilities Area and equipment from Test Area North. The CFA properties are among the few remaining permanent World War II structures in Idaho and consultation continues to determine their final disposition. The most challenging but visible preservation, however, was that of a lead-shielded locomotive used during the 1950s for the Aircraft Nuclear Propulsion Project and for later historically important projects at Test Area North. Through the efforts of CWI, in coordination with BEA, the locomotive was moved thirty-five miles south from TAN to the EBR I National Historic Landmark and Visitors Center and placed on permanent public display. A concrete pad and rail track were installed and the locomotive now resides next to the modified jet engines that it was initially designed to haul.

\subsection{Other Cultural Resource Reviews}

In FY 2006, 35 INL projects involving ground disturbance were screened for potential impacts to non-architectural cultural resources (Table 2). Resources of concern in these reviews were archaeological sites from the prehistoric and historic periods as well as intangible American Indian and stakeholder values and concerns. Two of the projects included in the FY 2006 total were located on lands in Idaho Falls, the remainder at various locations on the desert site. Archive reviews were completed for all of these projects and in many cases $(58 \%)$ they demonstrated that the proposed activities were located within areas that had already been intensively surveyed for archaeological resources. In most of these cases, the proposed projects could be completed with no impacts to known resources of National Register significance either because the original surveys resulted in no resources recorded or because identified resources were clearly outside the areas of potential effect for the work. In four cases, ground disturbance was located in or near the boundaries of known cultural resources and monitoring was completed to ensure that adverse effects did not occur.

Table 2. Non-architectural project reviews completed in FY 2006.

\begin{tabular}{|c|c|c|c|c|}
\hline Project \# & Project Name & INL CRMO Activities & $\begin{array}{l}\text { Acres } \\
\text { Surveved }\end{array}$ & $\begin{array}{l}\text { Cultural Resources } \\
\text { Identified }\end{array}$ \\
\hline BBWI-2006-01 & $\begin{array}{l}\text { PBF Monitoring: Bldg } 690 \\
\text { and } 632 \text { Waterlines }\end{array}$ & $\begin{array}{l}\text { Archive Review - } \\
\text { Monitoring - No Effect }\end{array}$ & & None \\
\hline BBWI-2006-02: & $\begin{array}{l}\text { Cell Tower at Auxiliary } \\
\text { Reactor Area }\end{array}$ & $\begin{array}{l}\text { Field Survey - No } \\
\text { historic properties }\end{array}$ & 1 acre & None \\
\hline BBWI-2006-03: & $\begin{array}{l}\text { Expanded Surveys of T-24 } \\
\text { and the Power Line Road }\end{array}$ & $\begin{array}{l}\text { Field Survey - Historic } \\
\text { properties identified }\end{array}$ & 231 acres & $\begin{array}{l}3 \text { Isolates } \\
19 \text { Sites } \\
\text { Unspecified American } \\
\text { Indian Resources }\end{array}$ \\
\hline BBWI-2006-04: & $\begin{array}{l}\text { PBF Monitoring: Research } \\
\text { Equipment Installation }\end{array}$ & $\begin{array}{l}\text { Archive Review - } \\
\text { Monitoring - No Effect }\end{array}$ & & None \\
\hline
\end{tabular}




\begin{tabular}{|c|c|c|c|c|}
\hline Project \# & Project Name & INL CRMO Activities & $\begin{array}{l}\text { Acres } \\
\text { Surveyed }\end{array}$ & $\begin{array}{l}\text { Cultural Resources } \\
\text { Identified }\end{array}$ \\
\hline BBWI-2006-05: & $\begin{array}{l}\text { Naval Reactor Facility } \\
\text { Projects }\end{array}$ & $\begin{array}{l}\text { Archive Review - No } \\
\text { historic properties }\end{array}$ & & None \\
\hline BBWI-2006-06: & $\begin{array}{l}\text { TAN Bldg } 687 \text { Drainfield } \\
\text { Expansion }\end{array}$ & $\begin{array}{l}\text { Archive Review - No } \\
\text { historic properties }\end{array}$ & & None \\
\hline BBWI-2006-07: & $\begin{array}{l}\text { Structural Collapse } \\
\text { Rescue Training Area at } \\
\text { CFA Fire Station }\end{array}$ & $\begin{array}{l}\text { Field Survey - No } \\
\text { historic properties }\end{array}$ & 1 acre & None \\
\hline BBWI-2006-08: & $\begin{array}{l}\text { Critical Infrastructure } \\
\text { Protection R\&D Testing }\end{array}$ & $\begin{array}{l}\text { Archive Review - No } \\
\text { historic properties }\end{array}$ & & None \\
\hline BBWI-2006-09: & Batch Plant at INTEC & $\begin{array}{l}\text { Archive Review - No } \\
\text { historic properties }\end{array}$ & & None \\
\hline BBWI-2006-10: & $\begin{array}{l}\text { MFC Design Basis Threat } \\
\text { Policy Modifications }\end{array}$ & $\begin{array}{l}\text { Archive Review - long } \\
\text { term recommendations }\end{array}$ & & \\
\hline BBWI-2006-11: & $\begin{array}{l}\text { FY } 2006 \text { Ordnance } \\
\text { Remediation }\end{array}$ & $\begin{array}{l}\text { Archive Review - long } \\
\text { term recommendations }\end{array}$ & & \\
\hline BBWI-2006-12: & $\begin{array}{l}\text { Vadose Zone Research } \\
\text { Park Improvements }\end{array}$ & $\begin{array}{l}\text { Archive Review - No } \\
\text { historic properties }\end{array}$ & & None \\
\hline BBWI-2006-13: & $\begin{array}{l}\text { FY } 2006 \text { Long Term } \\
\text { Ecological Studies }\end{array}$ & $\begin{array}{l}\text { Archive Review - } \\
\text { Monitoring - No Effect }\end{array}$ & & None \\
\hline BEA-2006-14: & $\begin{array}{l}\text { Mass Detonation Area } \\
\text { Container Tests }\end{array}$ & $\begin{array}{l}\text { Archive Review - No } \\
\text { historic properties }\end{array}$ & & None \\
\hline BEA-2006-15: & $\begin{array}{l}\text { USGS Gauging Station } \\
\text { Repairs at Pioneer and } \\
\text { Downstream }\end{array}$ & $\begin{array}{l}\text { Field Survey, Monitoring } \\
\text { - No Adverse Effect }\end{array}$ & 1 acre & 1 site \\
\hline BEA-2006-16: & $\begin{array}{l}\text { Mars Project Test Holes at } \\
\text { the Research Office } \\
\text { Building in Idaho Falls }\end{array}$ & $\begin{array}{l}\text { Archive Review - No } \\
\text { historic properties }\end{array}$ & & None \\
\hline BEA-2006-17: & $\begin{array}{l}\text { Science and Technology } \\
\text { Campus in Idaho Falls }\end{array}$ & $\begin{array}{l}\text { Field Survey }- \text { Historic } \\
\text { properties identified }\end{array}$ & 118 acres & $\begin{array}{l}\text { 1 Isolate } \\
2 \text { Sites }\end{array}$ \\
\hline BEA-2006-18: & $\begin{array}{l}\text { Big Lost River Rest Area } \\
\text { Improvements }\end{array}$ & $\begin{array}{l}\text { Field Survey - No } \\
\text { historic properties }\end{array}$ & 1 acre & None \\
\hline BEA-2006-19: & $\begin{array}{l}\text { Water Removal from the } \\
\text { Bldg } 603 \text { Basins at } \\
\text { INTEC }\end{array}$ & $\begin{array}{l}\text { Archive Review - No } \\
\text { historic properties }\end{array}$ & & None \\
\hline BEA-2006-20: & $\begin{array}{l}\text { Large Scale Explosive } \\
\text { Test Range }\end{array}$ & $\begin{array}{l}\text { Field Survey - Historic } \\
\text { properties identified }\end{array}$ & 164 acres & $\begin{array}{l}\text { Isolates } \\
12 \text { Sites } \\
\text { Unspecified American } \\
\text { Indian Resources }\end{array}$ \\
\hline BEA-2006-21: & $\begin{array}{l}\text { TAN Locomotive } \\
\text { Relocation }\end{array}$ & $\begin{array}{l}\text { Field Survey - No } \\
\text { historic properties }\end{array}$ & 1 acre & None \\
\hline BEA-2006-22: & $\begin{array}{l}\text { Door Testing Facility at } \\
\text { the Firing Range }\end{array}$ & $\begin{array}{l}\text { Archive Review - No } \\
\text { historic properties }\end{array}$ & & None \\
\hline BEA-2006-23: & $\begin{array}{l}\text { PBF Monitoring: } \\
\text { Continued DD\&D of } \\
\text { Reactor Complex }\end{array}$ & $\begin{array}{l}\text { Archive Review - } \\
\text { Monitoring - No Effect }\end{array}$ & & None \\
\hline BEA-2006-24: & $\begin{array}{l}\text { Bureau of Land } \\
\text { Management Fences }\end{array}$ & $\begin{array}{l}\text { Archive Review - long } \\
\text { term recommendations }\end{array}$ & & \\
\hline BEA-2006-25: & $\begin{array}{l}\text { Force-on-Force Training } \\
\text { Activities Around MFC }\end{array}$ & $\begin{array}{l}\text { Archive Review - No } \\
\text { historic properties }\end{array}$ & & None \\
\hline BEA-2006-26: & USGS Well 103 & $\begin{array}{l}\text { Field Survey - No } \\
\text { historic properties }\end{array}$ & 1 acre & None \\
\hline BEA-2006-27: & Stoller Reptile Traps & Field Survey - No & 3 acres & None \\
\hline
\end{tabular}




\begin{tabular}{|l|l|l|l|l|}
\hline Project \# & Project Name & INL CRMO Activities & $\begin{array}{l}\text { Acres } \\
\text { Surveyed }\end{array}$ & $\begin{array}{l}\text { Cultural Resources } \\
\text { Identified }\end{array}$ \\
\hline BEA-2006-28: & $\begin{array}{l}\text { Alternative Access Road } \\
\text { for TAN DD\&D Landfill }\end{array}$ & $\begin{array}{l}\text { historic properties } \\
\text { Archive Review - No } \\
\text { historic properties }\end{array}$ & None \\
\hline BEA-2006-29: & $\begin{array}{l}\text { Drainfield 724 Excavation } \\
\text { at RTC }\end{array}$ & $\begin{array}{l}\text { Archive Review - No } \\
\text { historic properties }\end{array}$ & None \\
\hline BEA-2006-30: & Stoller Sagebrush Study & $\begin{array}{l}\text { Archive Review - No } \\
\text { historic properties }\end{array}$ & None \\
\hline BEA-2006-31: & Section 110 Surveys & $\begin{array}{l}\text { Field Survey - Historic } \\
\text { properties identified }\end{array}$ & 156 acres & $\begin{array}{l}\text { 8 Isolates } \\
19 \text { Sites }\end{array}$ \\
\hline BEA-2006-32: & $\begin{array}{l}\text { Look Ahead Sensor Test } \\
\text { at Ryegrass Flats }\end{array}$ & $\begin{array}{l}\text { Archive Review - No } \\
\text { historic properties }\end{array}$ & None \\
\hline BEA-2006-33: & $\begin{array}{l}\text { ICP Weed Control and } \\
\text { Revegetation Areas }\end{array}$ & $\begin{array}{l}\text { Archive Review - No } \\
\text { historic properties }\end{array}$ & None \\
\hline BEA-2006-34: & $\begin{array}{l}\text { Next Generation Wireless } \\
\text { Test Bed Drive Test } \\
\text { Facility }\end{array}$ & $\begin{array}{l}\text { Field Survey - No } \\
\text { historic properties }\end{array}$ & 3 acres & None \\
\hline BEA-2006-35: & $\begin{array}{l}\text { Cold Test Pit Activities at } \\
\text { RWMC }\end{array}$ & $\begin{array}{l}\text { Archive Review - No } \\
\text { historic properties }\end{array}$ & None \\
\hline BEA-2006-36: & $\begin{array}{l}\text { Remote Treatment Project } \\
\text { at MFC }\end{array}$ & $\begin{array}{l}\text { Archive Review - No } \\
\text { historic properties }\end{array}$ & None \\
\hline
\end{tabular}

When the archive reviews completed in FY 2006 revealed adequate previous survey coverage and no danger of impacts to known cultural resources, recommendations for "clearance" were issued through the INL CRMO. Standard stipulations requiring work to stop in the event of any unanticipated discovery of cultural materials were included with each recommendation. A few of the archive searches for FY 2006 projects resulted in recommendations for future work. In these cases, projects were not scheduled for immediate completion and were located in areas that had never been surveyed for cultural resources or in areas where cultural resources are known to exist. Early involvement of the INL CRMO in project activities is beneficial to the projects, helping to prevent surprises and misunderstandings in the later stages of project execution.

Field surveys were necessary for $33 \%$ of FY 2006 projects proposed for areas on the INL and in Idaho Falls that had never been surveyed for cultural resources or in areas that were originally surveyed more than ten years ago. Approximately 681 acres were intensively examined during these project surveys and a wide variety of cultural resources were identified or re-identified and recommended for

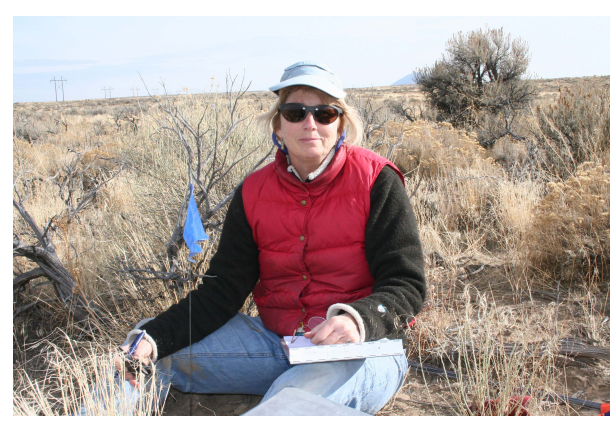

Dino Lowrey recording an archaeological site near T-24 avoidance or other protective measures. INL CRMO compliance with Section 110 of the National Historic Preservation Act also contributes to the totals in Table 2 (156 acres, 27 resources). The results of these surveys are described in detail in Section 5.3.1.2.

The largest project-related field survey of FY 2006 was completed to assemble comparative information on potential cultural resource impacts for two possible alternatives for construction of a new paved road to connect MFC with other internal INL facilities. Two existing trails, T-24 and the East Loop Powerline Road, were surveyed and/or resurveyed as part of the project (231 acres total) and roughly equal numbers of cultural resources were identified in the respective areas of 
potential effect for construction (22 total). Representatives from the Shoshone-Bannock Tribes provided valuable assistance during this survey project and expressed concerns about potential impacts to plants, animals, and other resources of importance to them. Recommendations to protect the National Register eligible archaeological resources and address American Indian concerns identified along the road corridors were included in the final report for this project (Pace et al. 2005), but as of this writing, the construction project is on hold.

Later in FY 2006, another sizable field survey was completed on remote INL lands north of the Materials and Fuels Complex (MFC, formerly Argonne National Laboratory-West) to assess the potential impacts of development of a Large Scale Explosive Research and Development Range (Pace et al. 2006). For this new project, archaeological surveys were completed of the R\&D test bed, new access roads and equipment laydown areas, as well as along an existing road that will require fairly extensive upgrades to provide ongoing access (164 acres total). Numerous archaeological sites were identified, particularly along the main access road (20 total), and Shoshone-Bannock tribal representatives expressed concerns regarding impacts to resources of interest to them. DOE-ID has taken these resources and concerns into account in an Environmental Assessment prepared for the project (DOE-ID 2006a).

Undeveloped lands near existing research and development facilities in Idaho Falls were targeted for FY 2006 cultural resource survey in anticipation of development of a consolidated and expanded Science and Technology Campus for INL programs (Pace 2006). Only two National Register-eligible resources and a single isolated artifact were identified in the large area of potential future development (118 acres) and these resources are considered along with Shoshone-Bannock interests in an Environmental Assessment prepared for the project (DOE-ID 2006b).

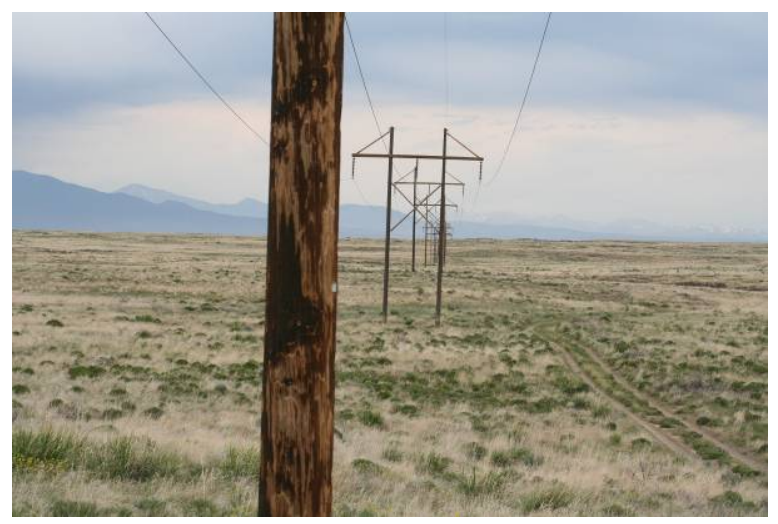

Large Scale Explosive Research and Development Range Survey Area

Shoshone-Bannock Tribal representatives received summary reporting of all archive searches completed in FY 2006, visited some of the project areas, and participated in one of the monitoring trips. In addition, all of the project locations that required new survey in FY 2006 were visited either during the actual fieldwork or on special tribal tours. Tribal representatives identified traditional cultural properties and other tribal concerns within the larger project areas discussed above during these visits. DOE-ID took these concerns into consideration as Environmental Assessments were prepared. No special tribal concerns were voiced for any of the other FY 2006 INL CRMO archive searches or small field surveys. Project plans were modified in all cases to avoid all of the archaeological resources identified. Cultural resource clearance recommendations issued for these projects also included a reminder of the requirements to stop work if any cultural materials were unexpectedly encountered. No test excavations were completed on the INL in FY 2006. 


\section{SITE AND PROJECT MONITORING}

A detailed description of the INL CRMO monitoring program is located in Appendix L of the INL CRMP (DOE-ID 2007) and a more detailed account of FY 2006 activities can be found in the INL Cultural Resource Monitoring Report for FY 2006 (INL-CRM 2005b). Monitoring enables the INL CRMO to document if the integrity of known resources is being compromised by natural processes, by unauthorized activities, or inadvertently by INL projects. By identifying impacts to cultural resources in this manner, actions to avert further deterioration can be initiated and federal stewardship responsibilities are fulfilled.

Specific cultural resources and INL projects are chosen for cultural resource monitoring based on feedback from DOE-ID and the Shoshone-Bannock Tribes as well as INL CRMO staff knowledge of INL projects and facilities. Each year, a select number of locations is developed and then targeted for visitation. The Shoshone-Bannock Tribes are typically involved in these monitoring activities. Project monitoring is limited by funding and must be responsive to the overall sensitivity of the resource and the level of project activity in any given year. For example, in the sandy aeolian soils within the Critical Infrastructure Test Range Complex (CITRC), where American Indian human remains have been found on two occasions, cultural resource monitoring of projects that involve excavation is routine and required by company procedure. This level of cultural resource oversight ensures that any additional human remains or cultural materials that might be encountered are handled appropriately. Cultural resource monitoring of other projects is typically done at the discretion of the CRMO and again, is responsive to overall levels and areas of activity across the entire area.

A number of locations, including the two at CITRC with human remains and the EBR I National Historic Landmark, are considered so sensitive that they are visited at least once, and in some cases more than once, each year. In FY 2006, no adverse conditions were noted at either EBR I or the two human interment locations. Five projects were monitored in FY 2006 and no additional finds were uncovered. Other locations visited on multiple occasions include Aviator's Cave, Middle Butte Cave, and the Pioneer Site. Proposed upgrades to road corridors led to monitoring work at 29 previously recorded archaeological sites and one historic trail. Other locations that were checked in FY 2006 include an historic Idaho Falls-area canal,

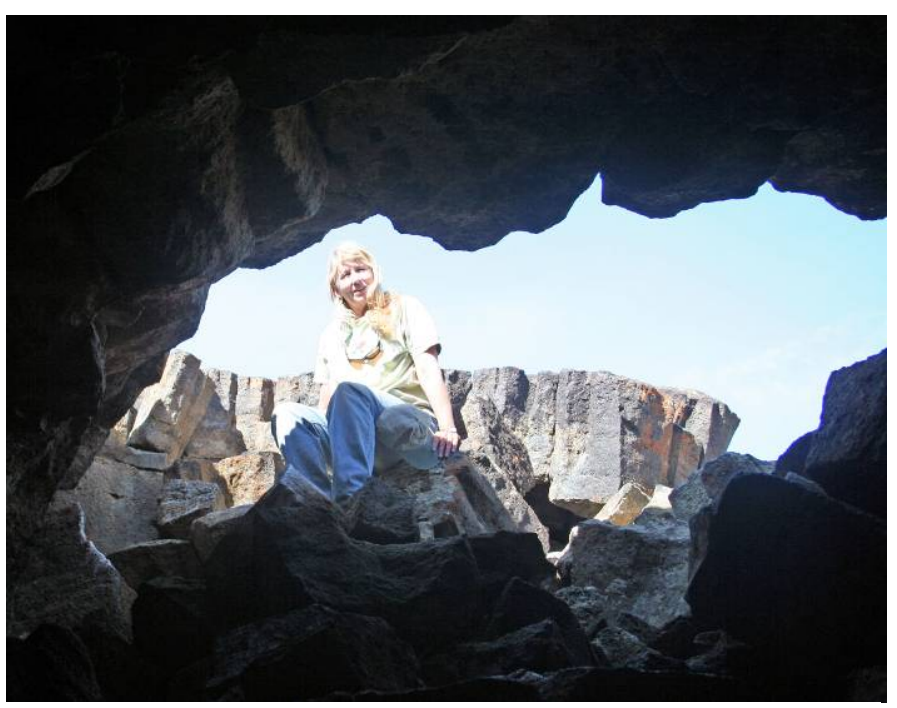

Dino Lowrey monitoring at Aviator's Cave

Radio Butte, and historic WWII era buildings located at CFA. In addition to site monitoring, three projects were monitored while underway. These included the CPP-603 Basin DD\&D and new Batch Plant, the new Vadose Zone Research Park, and a New U.S. Geologic Survey monitoring well. Although unauthorized visitation remains a problem at some locations and some sites have been damaged in the past, no new significant adverse effects to cultural resources were observed in FY 2006. 


\section{FISCAL YEAR 2007 ACTIVITIES}

Specific FY 2007 tasks are organized within the broad goals outlined in Section 5. At the time of this writing, FY 2007 work is well underway and many tasks are being planned, have been initiated or have already been completed.

\section{Goal 1: Identify and Manage INL Cultural Resources}

- $\quad$ Task 1: Review and update the INL Cultural Resource Management Plan.

- $\quad$ Task 2. Complete an inventory of MFC historic buildings.

- $\quad$ Task 3. Conduct two interviews of former INL employees.

- $\quad$ Task 4. Continue surveys along Big Lost River and Lake Terreton shoreline.

- $\quad$ Task 5. Develop identification criteria for historic Euro-American sites.

- $\quad$ Task 6. Revisit and re-record, if appropriate, select Euro-American sites.

- $\quad$ Task 7. Initiate inventory and classification of INL rock structures.

- $\quad$ Task 8. Update INL geographical information system files and server and continue quality control activities including resolution with Archaeology database.

\section{Goal 2: Evaluate National Register Eligibility of INL Properties for}

- $\quad$ Task 1. Evaluate the significance of select rock structures.

- $\quad$ Task 2. Prepare nominations for Aviator's Cave and CFA World War II structures.

\section{Goal 3: Monitor the Condition of INL Cultural Resources}

- $\quad$ Task 1. Develop a monitoring form more suitable for the observation of project activities and implement for at least two INL projects.

- $\quad$ Task 2. Visit, assess condition, and complete monitoring forms for Middle Butte, Aviator's, and Prickly Caves, the WERF burial, CFA World War II buildings (CF-606, CF-607, CF-613, and CF632) and implement protective actions as necessary.

\section{Goal 4: Protect INL Cultural Resources}

- $\quad$ Task 1. Participate in National Archives and Records Administration-sponsored training (Modern Archives Institute) toward achievement of certification as professional archivist.

- $\quad$ Task 2. Install cyberlock door into the temporary archive storage area.

- Task 3. Complete an initial appraisal of INL archival materials (i.e. documents, film, photographic negatives, architectural drawings, etc.). 
- $\quad$ Task 4. Review approximately ten compliance, procedural, and planning documents to integrate appropriate INL cultural resource management information.

- $\quad$ Task 5. Complete a structural assessment report for CFA World War II buildings (CF-606, CF607, CF-613, and CF-632).

\section{Goal 5: INL Artifact Curation}

- $\quad$ Task 1. Inventory artifacts in temporary storage at the INL CRMO.

- $\quad$ Task 2. Organize and participate in a visit to the Idaho Museum of Natural History to assess condition and security of INL artifacts.

- $\quad$ Task 3. Determine curation-related activities to be performed by the Idaho Museum of Natural History.

- $\quad$ Task 4. Input legacy site forms into the Archaeology database and continue ongoing quality control.

\section{Goal 6: Stakeholder Involvement/Public Outreach}

- Task 1. Participate in at least two educational events or tours.

- $\quad$ Task 2. Coordinate and conduct a stakeholder meeting/public tour of archaeological sites for Idaho Archaeology and Historic Preservation Month.

- $\quad$ Task 3. Track the number of tours and visitors on each tour.

- $\quad$ Task 4. Publish three Historic American Engineering Record reports and distribute.

- $\quad$ Task 5. Publish peer-reviewed articles.

- $\quad$ Task 6. Develop interpretive signage for World War II buildings, structures, and landscape at INL

\section{Goal 7: Interact with American Indians}

- $\quad$ Task 1. Assist DOE-ID counterpart in preparation of a presentation to the Tribal Business Council.

- $\quad$ Task 2. Participate in monthly Cultural Resource Working Group meetings.

- $\quad$ Task 3. Facilitate HeTO participation on archaeological fieldwork.

\section{Goal 8: Conduct Work Safely}

- $\quad$ Task 1. Conform to ISMS requirements.

- $\quad$ Task 2. Inspect equipment regularly.

\section{Goal 9: Maintain Professional Qualifications and Relationships}


- $\quad$ Task 1. Participate in training toward professional archivist certification.

- $\quad$ Task 2. Attend Society for American Archaeology meeting in April.

- $\quad$ Task 3. Meet once with the Idaho SHPO.

\section{Goal 10: Activities Reports/Plans}

- $\quad$ Task 1. Complete an annual report of activities conducted during the previous fiscal year.

- $\quad$ Task 2. Complete quarterly reports to Shoshone-Bannock HeTO.

- $\quad$ Task 3. Complete annual Department of Interior (DOI) questionnaire (Contract Data Requirements List [CDRL] F.45).

- $\quad$ Task 4. Complete annual monitoring report (CDRL F. 46).

- $\quad$ Task 5. Update INL Cultural Resource Management Plan as needed (CDRL F.47).

- $\quad$ Task 6. Prepare a nomination package for submittal to DOE-ID as requested (CDRL F.48). 


\section{REFERENCES}

Anderson, J. E., K. T. Ruppel, J. M. Glennon, K. E. Holte, and R. C. Rope, 1996, "Plant Communities, Ethnoecology, and Flora of the Idaho National Engineering Laboratory," Environmental Science and Research Foundation Report Series, Number 005, Idaho Falls, Idaho.

ARPA, 1979, “Archaeological Resources Protection Act, 1979," as amended, PL 96-95; 16 USC 470aa, et seq.

Braun, Julie, 2006, Change as an Historic Feature in the Preservation of Places Related to Science and Technology, MA thesis, Department of Historic Preservation, Goucher University, Baltimore, MD, 2206.

Bright, R. C., and O. K. Davis, 1982, "Quaternary Paleoecology of the Idaho National Engineering Laboratory, Snake River Plain, Idaho," American Midland Naturalist, 108(1):21-23.

Butler, B. Robert, 1968, “An Introduction to Archaeological Investigations in the Pioneer Basin Locality of Eastern Idaho," Tebiwa 11(1), pp. 1-30.

Butler, B. Robert, 1970, “A Report on the 1967-69 Archaeological Survey of the National Reactor Testing Station, Idaho," Tebiwa 13 (1), pp. 58-75.

Craig, T.H. and C. H. Trost 1976, "The Nesting Birds of the Idaho National Engineering Laboratory Site," Summaries of the Idaho National Engineering Laboratory Ecological Information Meeting, edited by O. Doyle Markham, Idaho Operations Office, U.S. Energy Research and Development Administration, Idaho Falls, Idaho.

Davis, Owen K. and Robert C. Bright, 1983, "Late Pleistocene Vegetation History of the Idaho National Engineering Laboratory," Idaho National Engineering Laboratory Radioecology and Ecology Programs 1983 Progress Report, edited by O.D. Markham, pp.162-171. U.S. Department of Energy. Idaho Operations Office, Idaho Falls, Idaho.

Department of Energy, Idaho Operations, 2007, Idaho National Laboratory Cultural Resource Management Plan, DOE/ID-10997, Revision 2, Idaho Falls, ID.

Department of Energy, Idaho Operations, 2006a, "Draft Environmental Assessment for the National Security Test Range," DOE/EA-1557, Idaho Falls.

Department of Energy, Idaho Operations, 2006b, Draft Environmental Assessment for the Proposed Expansion and Consolidation of Idaho National Laboratory Research and Development at a Science and Technology Campus," DOE/EA-1555, Idaho Falls.

Department of Energy, Idaho Operations, 2002, Agreement in Principle with the Shoshone-Bannock Tribes, December 2002.

Gerard, H. C., 1982, Wild Horse Jack, privately published, copyright Harry Clay Gerard.

Gianniny, Gary L., Glenn D. Thackray, Darrell S. Kaufman, Steven L. Forman, Michael J. Sherbondy, and Delda Findeisen, 2002, "Late Quaternary Highlands in the Mud Lake and Big Lost Trough Subbasins of Lake Terreton, Idaho," Geology, Hydrogeology, and Environmental Remediation: 
Idaho National Engineering and Environmental Laboratory, Eastern Snake River Plain, Idaho, Special Paper 353, pp. 77-90.

Henrikson, L. S. and B. R. Pace, 2006, "Between a Rock and a Hard Place: Late Holocene Defensive Structures on the Eastern Snake River Plain," paper presented at the $30^{\text {th }}$ Great Basin Anthropological Conference, Las Vegas, NV, October 19-21, 2006.

INL Cultural Resource Management Office, 2005a, "INL Cultural Resource Management Annual Report - FY 2005," INL/EXT-05-00937, Idaho Falls, Idaho.

INL Cultural Resource Management Office, 2005b, "INL Cultural Resource Monitoring Report for FY 2005," INL/EXT-05-00904. Idaho Falls, ID.

Mark, L. E. and G. D. Thackray, 2002, "Sedimentologic and Hydrologic Characterization of Surficial Sedimentary Facies in the Big Lost River Trough, Idaho National Engineering and Environmental Laboratory, Eastern Idaho," in Link, P. K. and Mink, L. L. (eds.) Geology, Hydrogeology, and Environmental Remediation: INEEL, Eastern Snake River Plain, Idaho, Geological Society of America Special Paper 353, pp. 61-75, Boulder, CO.

Marler, Clayton F., 2004, A Paleoindian Context for the Idaho National Engineering and Environmental Laboratory, MA thesis, Department of Anthropology, Idaho State University, Pocatello, Idaho.

Marler, Clayton F., 2006, "National Historic Preservation Act Section 110 Surveys for FY-2005," INL/EXT-06-11704, Idaho Falls, Idaho.

Miller, Susanne J., 1985, A Cultural Resources Inventory of the Perimeter Boundary, Grazing Boundary, and 1984 Project Areas, INEL, Southeastern Idaho. Report on file at the INL Cultural Resource Management Office, Idaho Falls, Idaho.

Nace, R. L., M. Deutsch, and P. T. Voegli, 1972, "Physical Environment of the National Reactor Testing Station, Idaho: A Summary," U.S. Geological Survey Professional Paper, 725-A, Washington, D.C.

NEPA, 1969, "National Environmental Policy Act of 1969," as amended, PL 91-190; 42 USC 4321 and $4331-4335$.

NHPA, 1966, "National Historic Preservation Act of 1966," as amended, PL 89-665; 16 USC 470, et seq.

Ostenaa, Dean A., Daniel R. Levish, Ralph E. Klinger, and Daniel R. H. O’Connell, 1999, "Phase 2 Paleohydrologic and Geomorphic Studies for the Assessment of Flood Risk for the Idaho National Engineering and Environmental Laboratory, Idaho," Geophysics, Paleohydrology, and Seismotectonics Group, Technical Service Center, Bureau of Reclamation, Denver, Colorado.

Pace, B. R., 2006, “Cultural Resource Assessment of Idaho National Laboratory's Expanded Science and Technology Campus in Idaho Falls," INL/EXT-06-11572, Idaho Falls, Idaho.

Pace, B. R., J. B. Braun, and H. K. Gilbert, 2006, "INL Fuel Reprocessing Complex Historic American Engineering Record Report: ID-33-H,” INL/EXT-06-11969, Idaho Falls, Idaho. 
Pace, B. R., H. K. Gilbert, and D. L. Lowrey, 2006, "Cultural Resource Assessment of the National and Homeland Security Research and Development Range at the Idaho National Laboratory," INL/EXT06-11517, Idaho Falls, Idaho.

Pace, B. R., C. F. Marler, H. K. Gilbert, D. L. Lowrey, and J. B. Braun, 2005, "Cultural Resource Assessment of the Power Line Road and T-24 at the Idaho National Laboratory," INL-EXT-0510133, Idaho Falls.

Plager, S. R., T. L. Johnson, A. Williams, and R. N. Holmer, 2004, "GIS Cultural Resource Predictive Model for the INL," Draft report, September 2004.

Ringe, B. L., 1995, Locational Analysis and Preliminary Predictive Model for Prehistoric Cultural Resources on the Idaho National Engineering Laboratory, MA thesis, Idaho State University, Department of Anthropology, Pocatello, Idaho.

Stacy, S., 2000, "Proving the Principle: A History of the Idaho National Engineering and Environmental Laboratory 1949-1999," DOE/ID-10799, Idaho Falls, Idaho.

Stacey, S., J. B. Braun, and H. K. Gilbert, 2006a , "Test Reactor Area, Materials Testing and Engineering Test Reactors Historic American Engineering Record Report: ID-33-G,” INL/EXT-06-01185, Idaho Falls, Idaho.

Stacey, S., J. B. Braun, and H. K. Gilbert, 2005, "Power Burst Facility and SPERT I, Historic American Engineering Record Report: ID-33-F,” ICP/EXT-05-00768, Idaho Falls, Idaho.

Stacey, S., J. B. Braun, and H. K. Gilbert, 2004, "Test Area North, Historic American Engineering Record Report: ID-33-E,” INEEL/EXT-04-02536, Idaho Falls, Idaho.

Stacey, S., J. B. Braun, and H. K. Gilbert, 1997a, “Advanced Reentry Vehicle Fuzing System, Historic American Engineering Record Report: ID-33-B,” INEEL/EXT-97-00066, Idaho Falls, Idaho.

Stacey, S., J. B. Braun, and H. K. Gilbert, 1997b, "Old Waste Calcining Facility, Historic American Engineering Record Report: ID-33-B,” INEEL/EXT-97-011370, Idaho Falls, Idaho.

Stacey, S., J. B. Braun, and H. K. Gilbert, 1994, "Test Area North Hangar, Historic American Engineering Record Report: ID-33-A,” INEL/EXT-94-0228, Idaho Falls, Idaho.

Sehman, R. and A.D. Linder, 1976, "A study of the Amphibian and Reptilian Fauna," Summaries the Idaho National Engineering Laboratory Ecological Information Meeting, edited by O. Doyle Markham, Idaho Operations Office, U.S. Energy Research and Development Administration, Idaho Falls, Idaho. 